\title{
Leadership Adaptation and Traits in Nepalese Police Forces
}

\author{
Thakur Mohan Shrestha \\ Singhania University Rajasthan, India \\ E-mail: thakurmohan@cef.edu.np
}

Received: 02-05- 2015

Accepted: $18-06-2015$

Published: 31-07-2015

doi:10.7575/aiac.ijels.v.3n.3p.1

URL: http://dx.doi.org/10.7575/aiac.ijels.v.3n.3p.1

\begin{abstract}
Recently, the role of leadership has been considered as one of the crucial factors for the success of any organization. However, what constitutes the effective leaders and what is the status of leaderships is still a subject of study. Hence, this research article is carried out with a mixed method. Based on the evaluation of 7 leadership styles, Bass and Avolio (1994)'s "5Is" behaviors, 49 traits, and 28 affecting elements for the development of police officers in Nepal, this study has used a survey questionnaire from $1111(\mathrm{~N})$ and in-depth interview from $21(\mathrm{~N})$ respondents from all the districts of Nepal. The findings of the study display that people are expecting a lot from police administration for adaptation of transformational leadership followed by participative/democratic, authentic and strategic models which were rated with highest ratings respectively. The trait status does not seem sound since the negative traits seem dominant with highest rating-' moderately to mostly', whereas the majority of positive traits are rated with 'a little to moderately'. Moreover, the transformational leadership behaviour is dealt with 'a little to moderately', which needs to be improved.
\end{abstract}

Keywords: Leadership Styles, Leadership Traits, Transformational Behavior, Security Concern Functions of the country

\section{Background}

What should be in the leadership is the theme of immense literatures in social sciences. God, Goddess, Gurus, Prophets, Priest, Kings, Chief, etc. denote the leaders in different timeline of history and religions. Veda, Geeta, Bible, Tipitaka, etc. are the guiding principles for their devotees and communities. The written concept and principle of leadership emerged early. The study of leadership can be dated back to Plato, Sun Tzu and Machiavelli; however, leadership as contemporary academic studies began only in the last 60 years back. The Egyptian hieroglyphs for leadership (seshemet), leader (Seshemu), and follower (Schmsu) were being written 5,000 years ago. In 2300 B. C. E., in the Instruction of Ptahhotep, three qualities were attributed to the pharaoh; their authoritative utterance is in thy mouth, perception is in the heart, and thy tongue is the shrine of justice (Litchtheim, 1973). Without effective leaderships, organizations move slowly sometimes and lose their way (Mills, 2005). One of the key issues of the next leadership transition will be the control over the domestic security apparatus (Puig, 2012). Service, safety and security (3Ss) are the obligatory role and responsibility of state and prerequisites for national development. A state is the means of rule over a sovereign territory. Above all, a nation mobilizes military and police forces. Leaderships are pivotal for nation building, peace and development. Police leaderships and policing in a democratic notion should be accountable to rule of law, people, and government.

The caste and family factors are being strongly questioned increasingly by intellectuals and Nepal has to go a long way in preparing leaders on the basis of traits of traditional society which continue to dominate at all levels (Baral, et al, and 2001). The dearth of literature of national periphery is disappointing. As a part of $\mathrm{PhD}$ research the study aims to provide an opportunity to advance in uncharted dome of leadership, traits and transformational behavior of police officers in the country.

\section{Research Objective}

Generally the objective of this research article is to explore the status of police leaderships with respect to responding the situations and to analyze the responses of the public, civil servants and security officers as to the leadership effectiveness of police administration. The specific objective is to examine the leadership model suitable for police administrations.

\section{Research Questions}

The following research questions are raised in this study:

3.1. RQ.1 What type of leadership style can be adopted in the internal security management of Nepal?

3.2. RQ.2 What is your perception/rating on traits of Nepalese police leaders (Nepal Police and Armed Police Force)?

3.3. RQ.3 What are your views and rating for Officers of National Police Forces on the basis of '5Is' behaviors?

3.4. RQ.4 What are the effecting elements for the development of police leadership in Nepal? 


\section{Review of Literature}

No society is known that does not have leadership in some aspects of their social life, although many may lack a single overall leader to make and enforce decisions (Bass, 2008). He pointed out that with the employment of different social sector and subsequent problem raised by this gave birth to transitional and Transformational leadership theory and described ways delaying with such problems. Stogdill (1974) Handbook of Leadership exposed a problem for understanding leadership that has, if anything, grown worse over the years: there are almost as many definitions of leadership as there are people attempting to define it. Leadership is one of the most observed and least understood phenomena on earth (Burns, 1978). Wide ranging review of the literature on leadership effectiveness came to an equally perplexing conclusion: most of the theories are beset with conceptual weaknesses and lack strong empirical support Yukl (1989). Maslow's hierarchy of needs is often portrayed in the shape of a pyramid with the largest, most fundamental levels of needs at the bottom and the need for self-actualization at the top (Simons et al, 1987). However, such literature in the context of Nepal still is not available, but might be fit.

\subsection{The Key Concept of}

Leadership is societal function within a group by motivation to organizational efforts for the satisfaction and effectiveness (Bass, 1990; Wren, 1995). Covey (2007) defines leadership as an ability to solve the group problem and influence others. Tancredi (2013) observed that a leader's role is not to give order to solve problem but to inspire. October 1937 witnessed dedication of spiritual leader Brahma Baba for the establishment and development of leadership with core values based on feminine qualities like patience, tolerance, sacrifice, kindness and love. Brahma increasingly needed as the foundation of progress in personal growth, human relations, and the development of caring communities (Brahma Kumaries; Tomlinson \& Manderson, 2012; Martin \& Gordan (2010). These key traits are still equally important for the development of ethical and transformational leadership development in developing countries like Nepal. According to Swami Vivekanda, Baba (1993); Chibber (1999); Usha (2002) and Covey (2007), leadership is made from cognitive ability and behavior outcomes. The post September 11th situation indicates the prime need of transformational leadership skills is shaped by team cohesiveness.

\subsection{Leadership theory and development overview}

Leadership is as old as the beginning of human civilization, so every great figure who contributed to a civilization became a leader (Dolezalek 2005; Salas \& Cannon-Bowers 2001; Vicere \& Fulmer 1996). A brief legend on the development of leadership theories is presented in Table 1 on the basis of previous research.

Table 1. Summary of Development Trends in Leadership Theory and Research

\begin{tabular}{|c|c|c|}
\hline Period & Approach & Core Them \\
\hline Before 1940 & Great-man & Leaders are born and not made \\
\hline 1930 to late $1940 \mathrm{~s}$ & Trait & Leadership ability is innate \\
\hline Late 1950 s to $1960 \mathrm{~s}$ & Behavioral & $\begin{array}{l}\text { Leaders can be made, rather than } \\
\text { are born }\end{array}$ \\
\hline $\begin{array}{l}\text { 1960s to early } \\
1980 \text { s }\end{array}$ & Situational \&Contingency & $\begin{array}{l}\text { It all depends; effective } \\
\text { leadership is affected by the } \\
\text { situation }\end{array}$ \\
\hline 1970 onward & $\begin{array}{l}\text { Contemporary Leaderships (Emotional Intelligence, } \\
\text { Servant, Team, Cross-cultural etc.). }\end{array}$ & Leadership by choice \\
\hline Since early 1980 s & $\begin{array}{l}\text { The 'New' Leadership (Transformational, Ethical, } \\
\text { Charisma) }\end{array}$ & Leadership by culture \\
\hline
\end{tabular}

Source: Insights from previous studies

Table 1 represents the model of leadership development. The leadership theories from great-man to transformational (including key contemporary leadership and dedications) are reviewed by the researcher of this study. Leadership in modern complex era has become a subject of emerging discussion to shift from traditional to global leadership, eleadership and alternative forms of different leadership for the better societies of the future. Transformational, ethical leadership and mixed models of leadership could be the main streams of leadership styles in developing countries like Nepal.

\subsection{A Brief Review on Leadership and the Future of Leadership Research}

Leadership has been shifted one form to another form. A trend line of leadership development theory is displayed in figure 1. 


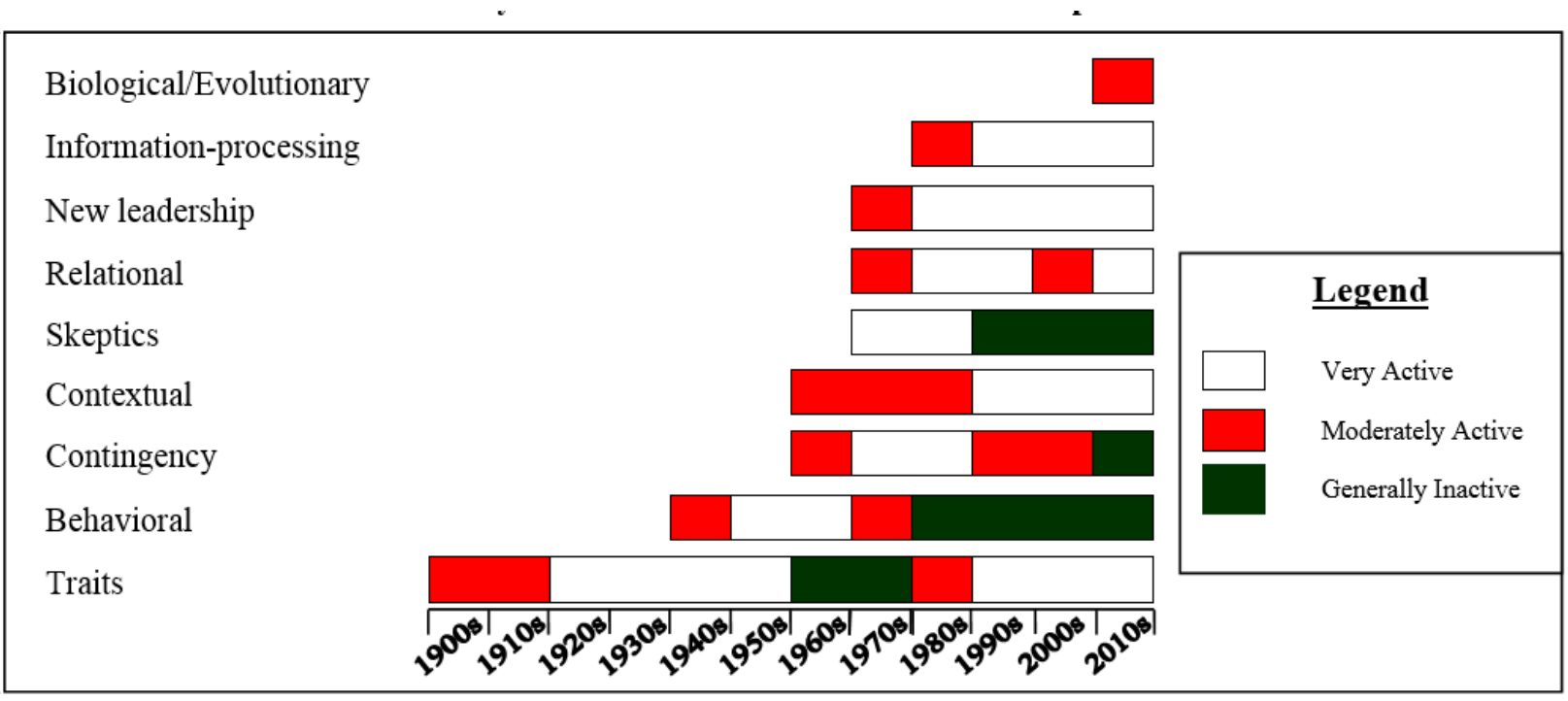

Figure 1. A Brief History and Look into the Future of Leadership Research

Source: The Nature of Leadership 2nd Edition, edited by David V. Day\& Jhon Antonakis (2012) Figure 1.1, Page 7, 2012. SAGE publication

As presented in Figure 1, based on the trends, it can be expressed that trait theory is the evergreen in nature because it was apparent from 1920s to 1050s as an active theory. Again, it becomes eminent from 1990 onwards. Other theory like information-processing becomes eminent with the rise of information technology (IT). Skeptics' theory emerged in 1970s but remained active for 20 years only. Contingency theory emerged in 1970s and lived up to 1980s only. However, how the leadership theories can be applied to the situations of Nepalese security services has not been investigated, so an urgent need is felt in this direction.

\subsection{Studies of Leadership Traits and Characteristics}

Different researches have indicated the trait theory as a naturally pleasing theory which gives a detailed knowledge and understanding of the leader element in the leadership process. The ANNEX I present the traits identified in different major researches. Trait theory is evergreen theory. But what are the 'traits' contained in traits theory? It is still a subject to study. It got changes over different periods for example in 1948 when Stogdill described 9 (nine) traits, when Mann explored 6 (six) traits, again in 1979 Stogdill and Alliger listed 10 (ten) traits, in 1986 Lord Devader and Locke suggested only 3 (three) traits, in 1991 Kirkpatrick Kemp, and Bader suggested 6 (six) traits, and Zaccaro in 2004 has given 11 (eleven) traits. The number of traits has changed (For detail ANNEX I).

There are eight main attitudes (ANNEX II): power to listen (patience), availability (humility), tolerance (love), adaptability (maturity), discrimination (knowledge), decision-making (clarity of mind), and ability to respond (courage) and team spirit (cooperation) which enables leadership abilities (Sis B. K. Usha, 2002). However there are 49 traits being discussed in the study.

\subsection{Police Leadership and Periphery}

Basically, police leadership is made from a mixture of visionary, behavioral and traits to motivate the public. It is experienced that plenty of research literatures are available on leadership and management, but a small number of researchers have paid attention in police leadership and issues. A police leader is responsible to actively persuade and mobilize support for the vision (Jim Isenberg, 2010). Leaders and the leadership processes will become more effective by comprehensively understanding these motivational facets of our behavior and by responsibly applying this knowledge when influencing the behavior of others. Contemporary society is often said to be suffering from a crisis in leadership (Moran, 1992) and Nepal is no exception.

\subsubsection{Diverse perceptions on police leadership}

Dobby et al. (2004) argue that police service get transformational leadership if they are appreciated by the best services they do for the people and make them feel proud. The noble leaders radiate their life to all members of teams. The accountability follows from highest level of the police Force to the police constable (Kalam, 2006). Value-led ethical leadership in policing maximizes effort by integrating prized community values into an agency's mission, vision, strategy, operating plans, and services (Meese III, \& Ortmeier, 2010). For the noblest job of police the question of structure has no meaning but culture of humanity, trust, love and respect has meaning. A good police force with effective intelligence is essential rather than arms and ammunition to care rule of law and to run government (Modi, 2014). Police organization serves for distinct purpose: service, safety, security, fundamental and universal rights. Fundamentally, police leaderships must exercise enlightened moral judgment and high ethical standards. 


\subsection{Women Police in Nepal at a glance}

Nepal is a country of heterogeneous group of casts and religions, so inclusive policy has been started. Nepal has three layers of security organizations: Nepal Army, Nepal Police and Armed Police force. In the Nepalese Army there are a total of 1776 (1.91\%) female personnel (Nepalese Army, 2015). Similarly, the status in Nepal Police is 5.3\%) and Armed Police Force $5.2 \%$ (ANNEX III).

\subsubsection{Women in Nepal Police(NP)}

First woman Police Constable Chaitamaya Dangol was recruited on 15th June 1951. Two dozen women were recruited for traffic management in 1968. At present Women and Children Service Centers are actively operating in 75 districts and 7 metropolitan circles in the Kathmandu valley. Establishment of special Woman Police Company -1986 and Traffic Woman Company was in 1995. The first women Police, inspector was Parbati Devi in Nepal. At present, 3572 of total 67416 women police personnel have been servicing in Nepal Police (ANNEX III).

\subsubsection{Women Armed Police Force (APF)}

The APF was established on $24^{\text {th }}$ October 2001, formally. Basically, its foundation is similar to the paramilitary force. During the establishment, women personnel were not encouraged and the number of women personnel was almost seventeen including technicians, and followers. On 11th April, APF Service Commission was formed and then women have been encouraged in open competition. Now a total of 1837 (including technician and flowers) women personnel are serving in APF. In APF, Gender units are expanded to Regional level (ANNEX: III).

\subsection{Challenges in Nepalese Milieu}

Internal threats like insurgency, poverty, education and health problem are challenging internal security (Rai, 2006). In this situation of such social disturbances police administration need IT (Information Technology) to meet effective communication to receive message from top to bottom and bottom to top (Rberson, 2007 \& Batts, 2012). Nonrepresentative and corrupt leaders and administrators who are in power are the major challenges because police must be under them and time again they take support from outside the country. This leads to external threats (Shrestha, 2004 \& Bhattrai, 2010). Maoist armed struggle has established violence as a method of political change and has revealed multifaceted challenges in national and public security (Sharma Wagle, 2010). People who are supported to corrupt themselves are from favoritism; honest people have low morale and degraded (Security sector agency modernization, High level action committee, 2012). Law enforcement is very weak (K. C., 2014). Inequality and exclusion are the key challenges to sustain democracy and maintain peace and social harmony in a post conflict situation of Nepal (Khatiwada, 2014). Mechanistic system does not work; system must be organic (Modi, 2014). '3Is': Injustice, Insecurity and Imbalance have been reflecting in the post transitional Nepal. The federalism debate is not clear and remains uncertain. Rising problem of dishonesty can be lacked in transformational leadership. All the threats of crime and criminal actions cannot be controlled by unprofessional and unfit executives of police forces who replaced honest police officers by hook and cook (Shrestha, 2015).

Poverty, unemployment, brain drain, youth drain, rampant corruption, emerging technology, open border, globalization cause and consequences, etc. are the products of the weakness of securities so the police administrations should not forget key threat and challenges of securities. It cannot be assured that the security threats of the past will not be repeated again In such situation how police forces can assure the people for peace is a subject to discuss. Indian Airlines flight-814 hijack(24th December, 1999) while flying from Kathmandu to Delhi, terrorist attack on Mumbai (26th November 2008), Peshawar school massacre (16th December 2014), in Afghanistan, tedious post conflict transitional status of the country, ongoing terrorist activates of Maoist in Jharkhand India, Bangladesh Rifle Revolt (25 and 26 February 2009) in Dhaka, Revolt by police and armed police personnel at Banke and Prabat district (2008), Royal palace massacre, murder of founder Chief Krishna Mohan Shrestha, of APF, small arms proliferations in landlocked Nepal are strategic challenges which should not be underestimated by all police administrations. Mainly, Chiefs of domestic security Deviram Sharma (NID); Shyam Thapa (NP), Shahabir Thapa(APF); along with potential leadership cadres like Additional Inspector General Rajendra Bahadur Sings and Additional Inspector General Rabi Raj Thapa were suspended from the role and responsibility and leading opportunity whereas the state machineries were under unified command led by military executives in the command posts. Chain of command and span of control are the fundamentals of unified command system and accountability goes to the commander. Similarly, unfair and unethical trends for selection and promotion for the unprofessional and unfit individual top executive like appointment of untrained and on groomed individual Architect Engineer Kosh Raj Onta as the Chief of APF (paramilitary force) against the values and norms of security force in 2012 by Maoist led government, which is the first example of clan culture system in the history of police and armed police force since 1950. Another rooted challenge, issue and grievance is 30 year service tenure which is symbolized 'BLACK DAY' in NP and NID and same applies in APF (more detail is in the 8th part with the analysis of figure 3). These are the result of immature decisions that need not be appeared in any welfare states. The universal values, norms and legal procedures can be the tools to tighten the national security forces in federal democratic notion of the country. Leading from front is essential in security forces of a developing country like Nepal.

\section{Research Methodology}

The study uses mixed model with Qual-Quan method. Mixed method opens the door to multiple methods, different worldviews, and different assumptions, as well as different forms of data collections and analysis (Creswell, 2009). This survey was taken in the time frame of 7th September, 2013 to May, 2014 in Nepal. Additionally, the in-depth face-to- 
face interviews were taken in time frame of 15th Jan, 2015 to 15th April, 2015. The following efforts were made to accomplish the study.

\subsection{Pilot survey}

A pilot survey from 51 respondents from the various sectors and personalities was conducted to ensure the research aims and objectives and felt informative and effective to make the final survey questionnaire more clear and purposeful. It also enabled the researcher to develop the necessary skills of rapport building, listening, probing while allowing the interview to flow.

\subsection{Data}

Both primary and secondary data were collected. For the purpose of primary data open-closed survey questionnaire and face to face interview were applied. Equally, previous dissertations, journals, library, book, report, digital sources were used as the secondary data sources.

\subsection{Sampling}

The convenience sampling was applied because of the nature, sensitivity and subject matter of the study arena and its technicality. The total number of respondents were $1111(\mathrm{~N})$ from all 75 districts of Nepal from the different ways of life. Table 2 and Figure 2 reflect the diversity, dimension and design of sampling of the survey. As far as the representativeness of the population is concerned, the sample size has covered $13.2 \%$ female, $86.5 \%$ male and other (non-gender) $0.3 \%$. From urban areas $41.6 \%$ and rural areas, $55.8 \%$ respondents participated in this survey research and 21 veteran executive respondents expressed their views. As presented in Table 2, among the respondents, $64.54 \%$ were from public sector, $28.08 \%$ were from national security sectors (Nepal Police, Nepal Armed Police Force, National Investigation Department, and Nepal Army) and 7.38\% were from Government civil services.

Table 2. Service Faculties of Respondents

\begin{tabular}{|c|c|c|c|}
\hline S.N. & $\begin{array}{l}\text { Service } \\
\text { Faculty }\end{array}$ & Number & $\begin{array}{l}\text { Percent } \\
(\%)\end{array}$ \\
\hline 1. & $\begin{array}{l}\text { Security } \\
\text { Officer }\end{array}$ & 312 & 28.08 \\
\hline 2. & Civil Servant & 82 & 7.38 \\
\hline \multirow[t]{2}{*}{3.} & Public Service & 717 & 64.54 \\
\hline & Total & 1111 & 100.00 \\
\hline
\end{tabular}

\section{Source: Self complied}

Figure 2 indicates the status of respondents on regional basis as per Nepal is divided into five development regions, fourteen Zones and seventy-five districts. The highest participation is $51.3 \%$ from central development region, where the capital city and almost all central level services and ministry, organizations, and business facilities are concentrated. Basically, all respondents were classified into two major categories (public private and national security) where Public Private was 71.9\% and National Security Sector (Nepal Army, Nepal Police Armed Police Force, and NID) were 28.1\% of the total.

\subsection{Instruments}

Open-ended and closed survey questionnaire with Likert's 5 scale rating, face -to -face interview, and a focus group discussion were applied in well-designed ways.

\subsection{Data Analysis}

Data were presented in frequency tables showing both numerical counts and corresponding percentages of responses on a psychologist Rensis Likert's 5-point scale indicating respondents' levels of concern in particular status, where the evaluation base was designed as mentioned in Table 3 .

Table 3. Five Scale Rating Scale

\begin{tabular}{ccccc}
\hline $\begin{array}{c}\text { Strongly Disagree or } \\
\text { Not at all }\end{array}$ & $\begin{array}{c}\text { Disagree } \\
\text { or A little }\end{array}$ & $\begin{array}{c}\text { Neutral } \\
\text { or Moderately }\end{array}$ & $\begin{array}{c}\text { Agree } \\
\text { or Mostly }\end{array}$ & $\begin{array}{c}\text { Strongly Agree } \\
\text { or Fully }\end{array}$ \\
\hline 1 & 2 & 3 & 4 & 5 \\
\hline
\end{tabular}


As displayed in Table 3, the five scale rating ranging from 1 to 5 is applied in survey approach throughout the study, where the highest scale is 5 and lowest is $1 \ldots$ The data obtained from this research has been analyzed using Interpretative Phenomenological Analysis (IPA) for qualitative appreciation. Statistic tools were used for quantitative explanation. The interview transcripts were analyzed individually and themes were identified. Highest priority has been given to secrecy and ethics of the research. 'SPSS' was used to calculate cross table information to revive demographic variables and its distribution with different leadership traits displayed by police administrations as the leaders. T-test, one way ANOVA, Chi-squared, Kendal's tau and Gamma tests were applied to receive the effects of experience, and qualifications towards the effectiveness of police administrators as the leaders.

\section{Findings and Discussion}

Below the researcher has presented the findings and discussions from survey, interview and observations and primary and secondary data on leadership, traits and behaviors of police administrators.

\subsection{Findings on Leadership style by survey}

The table presents respondents' views with the rating on each leadership style. The results are compiled in this section on the basis of rating, mean, t-test \& one way ANOVA test with major demography.

\subsection{Respondents' Rating on Different Leadership Style}

Table 4. Status of Rating on Leadership Style for Adaptation with Mean Values

\begin{tabular}{lllllllll}
\hline & Leadership Styles & Missing & $\begin{array}{l}\text { Strongly } \\
\text { Disagree } \\
\text { \% }\end{array}$ & $\begin{array}{l}\text { Disagree } \\
\text { \% }\end{array}$ & $\begin{array}{l}\text { Neutral } \\
\text { \% }\end{array}$ & $\begin{array}{l}\text { Agree } \\
\text { \% }\end{array}$ & $\begin{array}{l}\text { Strongly } \\
\text { Agree \% }\end{array}$ & $\begin{array}{l}\text { Mean } \\
\text { S.N. }\end{array}$ \\
\hline 1 & Transformational & 0.81 & 1.53 & 3.96 & 8.46 & 52.93 & 32.31 & 4.08 \\
2 & Authentic & 0.54 & 1.26 & 3.87 & 15.39 & 53.74 & 25.20 & 3.96 \\
3 & Participative/Democratic & 0.45 & 2.61 & 8.01 & 8.82 & 52.39 & 27.72 & 3.93 \\
4 & Strategic & 1.17 & 1.98 & 6.75 & 20.16 & 48.78 & 21.15 & 3.77 \\
5 & Task-Oriented & 0.90 & 1.80 & 6.93 & 22.68 & 47.79 & 19.89 & 3.74 \\
7 & Supportive & 1.53 & 2.07 & 5.58 & 26.73 & 46.17 & 17.91 & 3.68 \\
\hline
\end{tabular}

Source: Field Survey

Table 4 reflects the status of respondents rating on aforementioned seven leadership styles. Majority of the respondents $32.31 \%$ strongly agreed and $52.93 \%$ agreed to Transformational leadership. It shows $85.24 \%$ with mean value 4.08 have agreed for the adoption of transformational leadership in the country. Authentic (mean 3.96) \& participative/democratic (3.93) leadership were rated 2nd and 3rd status among the seven style. The situational leadership respondent had been rated with mean value 3.49 which was the lowest rating among seven leadership styles. In brief, it is revealed that most people, civil servants and security officers like transformational leadership style.

6.3 Summary of Independent sample t-test and one-way ANOVA test result of Leadership on the basis of different demography

Table 5. Independent sample t-test and ANOVA test Summary Result of by on Key Demography

\begin{tabular}{|c|c|c|c|c|c|c|c|c|c|c|}
\hline \multirow[b]{2}{*}{ Leadership } & \multicolumn{2}{|c|}{ Gender } & \multicolumn{2}{|l|}{ Age } & \multicolumn{2}{|c|}{ Education } & \multicolumn{2}{|c|}{ Occupation } & \multicolumn{2}{|c|}{ Designation } \\
\hline & significant & $\begin{array}{l}\text { not } \\
\text { Significant }\end{array}$ & significant & $\begin{array}{l}\text { not } \\
\text { Significant }\end{array}$ & significant & $\begin{array}{l}\text { not } \\
\text { Significant }\end{array}$ & significant & $\begin{array}{l}\text { not } \\
\text { Significant }\end{array}$ & significant & $\begin{array}{l}\text { not } \\
\text { Significant }\end{array}$ \\
\hline Authentic & - & 0.147 & 0.026 & - & - & 0.379 & 0.046 & - & 0.010 & - \\
\hline $\begin{array}{l}\text { Participative/ } \\
\text { Democratic }\end{array}$ & - & 0.342 & - & 0.893 & - & 0.133 & - & 0.178 & 0.041 & - \\
\hline Situational & - & 0.089 & - & 0.211 & - & 0.956 & - & 0.249 & 0.045 & - \\
\hline Strategic & - & 0.684 & - & 0.452 & 0.000 & - & 0.002 & & 0.010 & - \\
\hline Supportive & - & 0.149 & - & 0.733 & - & 0.068 & - & 0.209 & - & 0.344 \\
\hline Task-Oriented & - & 0.832 & - & 0.564 & 0.031 & - & 0.002 & - & 0.000 & \\
\hline Transformational & - & 0.080 & - & 0.198 & - & 0.457 & - & 0.729 & - & 0.100 \\
\hline
\end{tabular}


Table 5 represents the Summary of independent sample t-test and one-way ANOVA test result of Leadership on the basis of different demography (ANNEX IV). Gender: For all the leadership styles: Authentic, Participative/ Democratic, Situational, Strategic, Supportive, Task-oriented and Transformational leadership; it is no significant with male and female. This means that due to the gender differences opinion do not differ. Age: ANOVA test shows that there is not significant statistical effect of age on the response. However, authentic leadership has statistically significant difference from p value 0.026. Education: Strategic and task oriented leadership styles were significantly differed due to the difference in education level of the respondents. Highly educated respondents favored the strategic leadership style. Similarly, result is found in case of task oriented leadership style. It can be concluded that highly educated respondents like to see their leaders following strategic leadership style as task oriented leadership style. Occupation: (Security officer \& Public) To examine the status of responses on leadership from the occupation perspective, the result shows there is statistically significantly difference in authentic, strategic and task oriented leadership with $\mathrm{p}$ value $0.046,0.002 \& 0.002$ respectively. Rest has not statistically significant difference. Designation: To examine the status of responses on leadership from the designation perspective, the result shows there is a statistically significant difference in opinions for supportive and transformational leadership with p $0.344 \& 0.100$ respectively. Rest has statistically significant difference.

\subsection{Crosstab with various variables on Leadership}

Crosstab result on leadership style is displayed in Annex 3. Table of crosstab between age and leadership presents that the age group of 41 to 50 have rated highest rating $23.94 \%$ to Transformational leadership (1st position), and 22.86 $\%$ to Authentic (2nd position), $22.59 \%$ to Participative/Democratic (3rd position) among seven style of leadership. This displays that emerging youth group like (ANNEX V).

\subsection{Summary of Leadership on different demographic variables}

Table 6. Status of Leadership Style on Key Demography

\begin{tabular}{|c|c|c|c|c|c|c|}
\hline \multirow[t]{2}{*}{ S.N. } & \multirow[t]{2}{*}{ Leadership Style } & \multicolumn{4}{|c|}{ Demographic Variable } & \multirow[b]{2}{*}{ Designation } \\
\hline & & $\begin{array}{l}\text { Overall } \\
\text { Result }\end{array}$ & $\begin{array}{l}\text { High } \\
\text { Education }\end{array}$ & $\begin{array}{l}\text { Security } \\
\text { Officer }\end{array}$ & $\begin{array}{l}\text { Public } \\
\text { Private }\end{array}$ & \\
\hline 1. & Authentic & & & $\sqrt{ }$ & & $\sqrt{ }$ \\
\hline 2. & Participative/ Democratic & & & & & $\sqrt{ }$ \\
\hline 3. & Situational & & & & $\sqrt{ }$ & $\sqrt{ }$ \\
\hline 4. & Strategic & & $\sqrt{ }$ & $\sqrt{ }$ & & $\sqrt{ }$ \\
\hline 5. & Supportive & & & & $\sqrt{ }$ & \\
\hline 6. & Task-Oriented & & $\sqrt{ }$ & & $\sqrt{ }$ & $\sqrt{ }$ \\
\hline 7. & Transformational & $\sqrt{ }$ & & $\sqrt{ }$ & $\sqrt{ }$ & $\sqrt{ }$ \\
\hline
\end{tabular}

Source: Self complied

Table 6 represents the summary of leadership rated by different demographics, where overall highest rating is on transformational leadership. Highly educated respondents are in favor of Strategic and Task oriented leadership styles. Security officers intend transformational and authentic leaderships. Service faculty (public) has rated transformational, task oriented, supportive, strategic, and situational leaderships and from the views of designation high ranking respondents rated almost all six leadership styles excluding supportive style of leadership.

6.6 Findings on Armed Police officers traits by survey on the basis of 49 variables

Altogether forty-nine variables in the Likert's 5 scale evaluation design format were submitted in survey questionnaire in alphabetic order to examine the prevailing status of police officer traits in Nepal. Almost ideal traits and a few key negative traits were combined in the survey. Table 7 and 8 represent the status of rating on each variable by respondents on the prevailing traits of both: Nepal police and Armed Police administrators.

Table 7. Traits of Armed Police Force Officers

\begin{tabular}{llllllllll}
\hline $\begin{array}{l}\text { S. } \\
\mathbf{N}\end{array}$ & Officers Traits & $\begin{array}{l}\text { Missing } \\
\%\end{array}$ & $\begin{array}{l}\text { Not at } \\
\text { all \% }\end{array}$ & $\begin{array}{l}\text { A } \\
\text { little \% }\end{array}$ & $\begin{array}{l}\text { Moderately } \\
\%\end{array}$ & $\begin{array}{l}\text { Mostly } \\
\%\end{array}$ & $\begin{array}{l}\text { Fully } \\
\%\end{array}$ & Mean & Remarks \\
\hline 1 & Stressful & 1.62 & 3.06 & 15.48 & 25.92 & 29.43 & 24.48 & 3.52 & Moderately to Mostly \\
2 & Status-Quo & 1.71 & 6.57 & 17.28 & 21.42 & 29.70 & 23.31 & 3.41 & Moderately to Mostly \\
3 & Suspicious & 1.53 & 4.50 & 21.33 & 28.35 & 22.86 & 21.42 & 3.31 & Moderately to Mostly \\
4 & Egoistic & 1.53 & 6.48 & 22.68 & 25.11 & 25.65 & 18.54 & 3.23 & Moderately to Mostly \\
5 & Flexible & 2.43 & 11.97 & 13.50 & 26.73 & 25.38 & 19.98 & 3.21 & Moderately to Mostly \\
6 & Pretending & 2.16 & 7.65 & 21.87 & 25.20 & 22.59 & 20.52 & 3.20 & Moderately to Mostly \\
7 & Intelligent \& Educated & 2.16 & 12.96 & 13.86 & 26.55 & 27.18 & 17.28 & 3.15 & Moderately to Mostly \\
8 & Prejudiced & 1.71 & 13.68 & 23.49 & 15.57 & 20.61 & 24.93 & 3.14 & Moderately to Mostly \\
9 & Willingness to take Risk & 2.25 & 8.91 & 12.69 & 34.65 & 32.04 & 9.45 & 3.14 & Moderately to Mostly
\end{tabular}




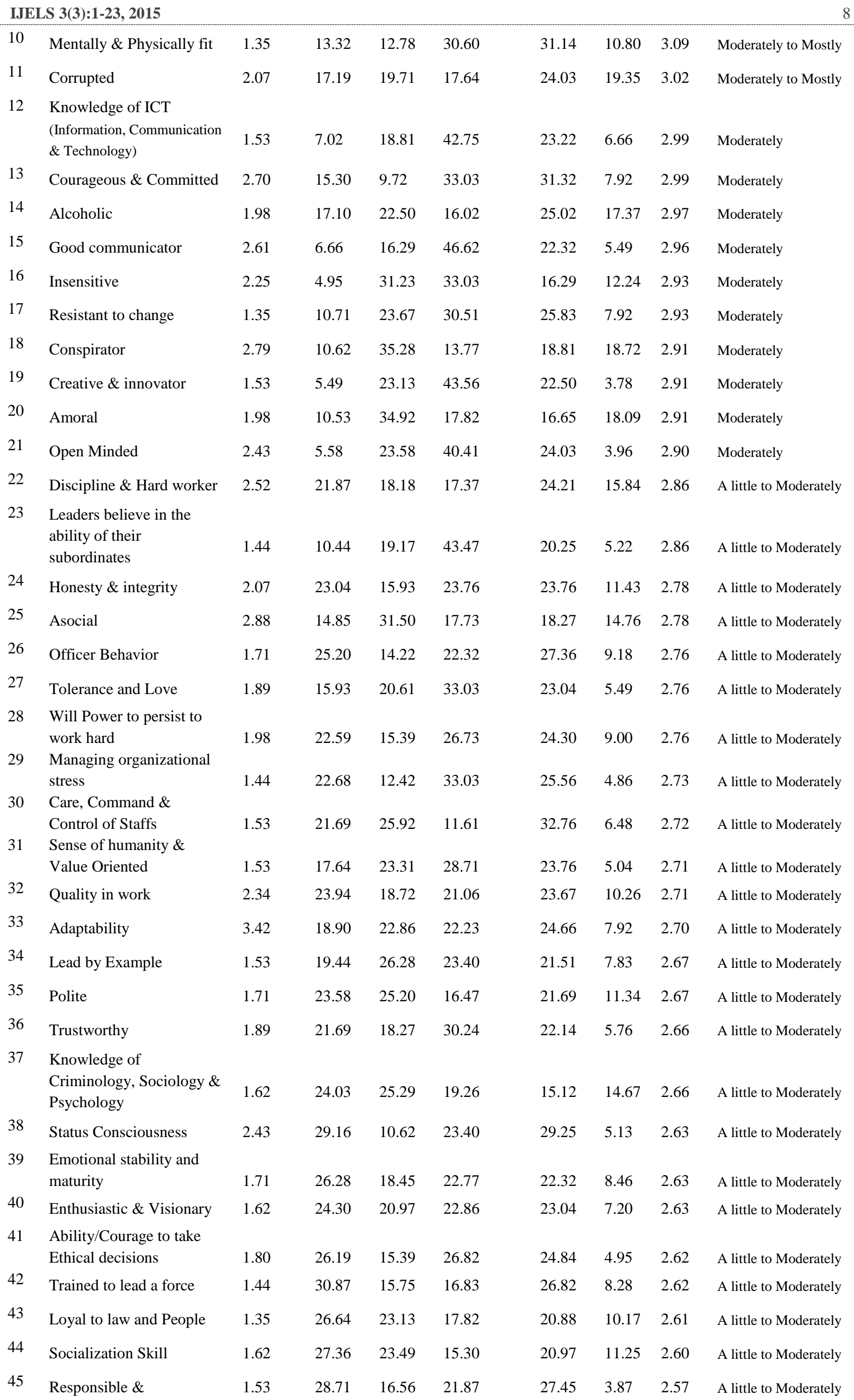




\begin{tabular}{|c|c|c|c|c|c|c|c|c|c|}
\hline & Accountable & & & & & & & & \\
\hline 46 & Inspiring Leadership & 1.44 & 25.92 & 21.51 & 21.06 & 25.92 & 4.14 & 2.57 & A little to Moderately \\
\hline 47 & Team Spirit Co-Operation & 1.44 & 36.27 & 14.22 & 17.10 & 24.66 & 6.30 & 2.46 & A little to Moderately \\
\hline 48 & Exceptional Quality & 2.88 & 24.75 & 29.52 & 20.88 & 18.54 & 3.42 & 2.38 & A little to Moderately \\
\hline 49 & $\begin{array}{l}\text { Capacity for abstract } \\
\text { thought }\end{array}$ & 1.35 & 26.73 & 31.68 & 18.18 & 18.00 & 4.05 & 2.37 & A little to Moderately \\
\hline
\end{tabular}

\section{Source: Field Survey}

Table 7 presents the status of Armed Police Administrators' traits as rated by the respondents in Likert's 5 scales. The research was conducted in post conflict transitional and unstable political situation of the country. Out of forty nine traits, few negative traits like alcoholic, amoral, asocial, corrupted, egoistic, prejudiced, pretending, stressful, statusquo(resisting to bring change), were examined and rest were positive traits in survey questionnaire. Almost out of ten traits seven negative traits have occupied the position with highest rating with the mean value 3.02 to 3.52 in the series as remarked 'moderately to mostly'. Serial numbers from 12 to 21 are almost 'moderately' rating with mean vale 2-90 to 2.99. Rests are in 'a little to moderately' with mean value range from 2.37 to 2.86 .

Table 8. Traits of Nepal Police Officers

\begin{tabular}{|c|c|c|c|c|c|c|c|c|c|}
\hline S.N & Officers Traits & $\begin{array}{l}\text { Missin } \\
\text { g \% }\end{array}$ & $\begin{array}{l}\text { Not at } \\
\text { all \% }\end{array}$ & $\begin{array}{l}\text { A } \\
\text { little \% } \\
\end{array}$ & $\begin{array}{l}\text { Moderately } \\
\% \\
\end{array}$ & $\begin{array}{l}\text { Mostly } \\
\% \\
\end{array}$ & $\begin{array}{l}\text { Fully } \\
\% \\
\end{array}$ & Mean & Remarks \\
\hline 1 & Suspicious & 1.17 & 3.96 & 16.20 & 22.68 & 32.40 & 23.58 & 3.52 & Moderately to Mostly \\
\hline 2 & Stressful & 1.26 & 4.05 & 14.04 & 27.00 & 34.74 & 18.90 & 3.47 & Moderately to Mostly \\
\hline 3 & Status-Quo & 0.99 & 8.37 & 17.01 & 24.75 & 26.82 & 22.05 & 3.34 & Moderately to Mostly \\
\hline 4 & Egoistic & 1.62 & 8.01 & 18.18 & 24.75 & 26.55 & 20.88 & 3.29 & Moderately to Mostly \\
\hline 5 & Pretending & 2.07 & 6.21 & 22.77 & 25.02 & 24.12 & 19.80 & 3.22 & Moderately to Mostly \\
\hline 6 & Alcoholic & 1.26 & 12.69 & 14.49 & 26.37 & 28.62 & 16.56 & 3.18 & Moderately to Mostly \\
\hline 7 & Prejudiced & 1.53 & 7.74 & 23.76 & 25.38 & 23.40 & 18.18 & 3.16 & Moderately to Mostly \\
\hline 8 & Corrupted & 1.89 & 14.04 & 13.59 & 23.49 & 31.59 & 15.39 & 3.15 & Moderately to Mostly \\
\hline 9 & Asocial & 2.07 & 13.68 & 23.04 & 14.76 & 22.50 & 23.94 & 3.14 & Moderately to Mostly \\
\hline 10 & Flexible & 2.16 & 10.26 & 16.02 & 29.70 & 28.53 & 13.32 & 3.12 & Moderately to Mostly \\
\hline \multirow[t]{2}{*}{11} & Knowledge of Criminology, & & & & & & & & \\
\hline & Sociology \& Psychology & 1.08 & 16.74 & 23.04 & 13.05 & 29.97 & 16.11 & 3.02 & Moderately to Mostly \\
\hline 12 & Amoral & 1.35 & 12.69 & 29.07 & 20.43 & 19.62 & 16.83 & 2.95 & Moderately \\
\hline 13 & Socialization Skill & 1.35 & 7.11 & 28.53 & 29.25 & 27.27 & 6.48 & 2.93 & Moderately \\
\hline 14 & Willingness to take Risk & 2.61 & 9.36 & 27.90 & 23.49 & 25.65 & 10.98 & 2.93 & Moderately \\
\hline 15 & Intelligent \& Educated & 1.98 & 12.51 & 20.52 & 26.19 & 33.66 & 5.13 & 2.92 & Moderately \\
\hline 16 & Mentally \& Physically fit & 0.99 & 9.72 & 27.36 & 30.15 & 22.32 & 9.45 & 2.91 & Moderately \\
\hline 17 & Status Consciousness & 2.25 & 9.45 & 21.78 & 33.21 & 28.80 & 4.50 & 2.90 & Moderately \\
\hline 18 & Discipline \& Hard worker & 2.07 & 14.31 & 21.33 & 26.19 & 26.01 & 10.08 & 2.90 & Moderately \\
\hline \multirow[t]{2}{*}{19} & Sense of humanity \& Value & & & & & & & & \\
\hline & Oriented & 1.08 & 8.28 & 24.39 & 37.08 & 24.21 & 4.95 & 2.90 & Moderately \\
\hline 20 & Creative \& innovator & 0.99 & 12.87 & 23.85 & 28.53 & 25.74 & 8.01 & 2.89 & A little to Moderately \\
\hline 21 & Resistant to change & 1.17 & 9.63 & 31.86 & 23.31 & 25.20 & 8.82 & 2.88 & A little to Moderately \\
\hline 22 & Quality in work & 2.07 & 8.82 & 23.94 & 34.92 & 25.29 & 4.95 & 2.87 & A little to Moderately \\
\hline \multirow[t]{2}{*}{23} & Capacity for abstract & & & & & & & & \\
\hline & thought & 1.17 & 18.81 & 17.73 & 25.47 & 27.72 & 9.09 & 2.87 & A little to Moderately \\
\hline 24 & Trained to lead a force & 1.17 & 13.05 & 28.71 & 21.78 & 25.56 & 9.72 & 2.87 & A little to Moderately \\
\hline 25 & Responsible \& Accountable & 1.17 & 9.09 & 24.84 & 33.93 & 29.07 & 1.89 & 2.86 & A little to Moderately \\
\hline 26 & Officer Behavior & 1.71 & 14.67 & 26.64 & 22.05 & 25.02 & 9.90 & 2.84 & A little to Moderately \\
\hline 27 & Tolerance and Love & 1.53 & 7.74 & 29.79 & 34.38 & 23.13 & 3.42 & 2.80 & A little to Moderately \\
\hline 28 & Good communicator & 2.79 & 22.77 & 17.19 & 20.07 & 24.84 & 12.33 & 2.78 & A little to Moderately \\
\hline 29 & Open Minded & 2.34 & 18.45 & 24.12 & 20.79 & 22.32 & 11.97 & 2.78 & A little to Moderately \\
\hline 30 & Team Spirit Co-Operation & 1.26 & 15.21 & 26.37 & 25.38 & 27.81 & 3.96 & 2.75 & A little to Moderately \\
\hline 31 & Insensitive & 1.80 & 16.74 & 26.10 & 26.10 & 18.99 & 10.26 & 2.75 & A little to Moderately \\
\hline 32 & Courageous \& Committed & 2.07 & 15.30 & 25.92 & 26.55 & 23.13 & 7.02 & 2.74 & A little to Moderately \\
\hline \multirow[t]{2}{*}{33} & Managing organizational & & & & & & & & \\
\hline & stress & 1.53 & 16.29 & 21.42 & 33.12 & 22.32 & 5.31 & 2.74 & A little to Moderately \\
\hline \multirow[t]{2}{*}{34} & Ability/Courage to take & & & & & & & & \\
\hline & Ethical decisions & 1.80 & 13.50 & 26.46 & 29.70 & 24.21 & 4.32 & 2.74 & A little to Moderately \\
\hline
\end{tabular}




\begin{tabular}{|c|c|c|c|c|c|c|c|c|c|}
\hline \multirow[t]{2}{*}{35} & \multicolumn{9}{|l|}{ Care, Command \& Control } \\
\hline & of Staffs & 1.26 & 17.64 & 24.21 & 26.28 & 27.72 & 2.88 & 2.70 & A little to Moderately \\
\hline 36 & Loyal to law and People & 0.90 & 18.72 & 28.08 & 23.76 & 18.99 & 9.54 & 2.70 & A little to Moderately \\
\hline 37 & Polite & 1.35 & 19.98 & 30.42 & 16.65 & 20.07 & 11.52 & 2.69 & A little to Moderately \\
\hline 38 & Honesty \& integrity & 1.71 & 23.13 & 22.86 & 23.40 & 16.92 & 11.97 & 2.67 & A little to Moderately \\
\hline 0 & Emotional stability and & & & & & & & & \\
\hline \multirow{3}{*}{40} & maturity & 1.35 & 23.04 & 20.16 & 23.22 & 27.72 & 4.50 & 2.66 & A little to Moderately \\
\hline & Knowledge of ICT & & & & & & & & \\
\hline & $\begin{array}{l}\text { (Information ,Communication } \\
\& \text { Technology) }\end{array}$ & 1.26 & 22.59 & 25.83 & 17.55 & 25.20 & 7.56 & 2.66 & A little to Moderately \\
\hline 41 & $\begin{array}{l}\text { Will Power to persist to } \\
\text { work hard }\end{array}$ & 1.62 & 13.86 & 30.96 & 30.42 & 19.62 & 3.51 & 2.63 & A little to Moderately \\
\hline 42 & Trustworthy & 1.80 & 18.18 & 27.18 & 25.65 & 22.59 & 4.59 & 2.63 & A little to Moderately \\
\hline 43 & Conspirator & 1.98 & 22.77 & 25.11 & 19.89 & 22.14 & 8.10 & 2.62 & A little to Moderately \\
\hline 44 & Inspiring Leadership & 1.17 & 26.37 & 21.51 & 21.78 & 18.81 & 10.35 & 2.62 & A little to Moderately \\
\hline 45 & Adaptability & 2.97 & 24.12 & 14.76 & 27.27 & 28.62 & 2.25 & 2.61 & A little to Moderately \\
\hline 46 & Enthusiastic \& Visionary & 1.53 & 22.86 & 23.31 & 23.67 & 24.21 & 4.41 & 2.59 & A little to Moderately \\
\hline 47 & Leaders believe in the & & & & & & & & \\
\hline & ability of their subordinates & 0.99 & 22.23 & 29.61 & 20.97 & 21.15 & 5.04 & 2.54 & A little to Moderately \\
\hline 48 & Lead by Example & 1.17 & 26.19 & 29.34 & 15.03 & 20.16 & 8.10 & 2.51 & A little to Moderately \\
\hline 49 & Exceptional Quality & 1.89 & 25.20 & 27.27 & 21.15 & 17.46 & 7.02 & 2.48 & A little to Moderately \\
\hline
\end{tabular}

Source: Field Survey

As in Table 7, the Table 8 also presents the status of Nepal police Administrators' traits. Almost the result is similar but not the same. Out of ten traits, nine negative traits have occupied the position with highest rating with the mean value 3.02 to 3.52 in the series as remarked 'moderately to mostly'. Whereas Serial no 12 to 19 have been rated 'moderately' with mean value 2.90 to 2.95 . Rest are rated 'a little to moderately' with mean value ranging from 2.48 to 2.89 . The situation in both Tables 7 and 8 present that the quality, which must be on the merit list for a good leadership has not been rated on top but as the lastly possessed by police officers. This signifies that police have to do a lot of efforts in developing the good traits sincerely. The result of the rating could be the firmed feedback to the stakeholders and all the rank and files of national police forces. Therefore, reformation and transformation approaches through the training, selfactualization and leadership supervision and instruction can be effective. Especially, research on the reason behind the cause and consequences is strongly recommended.

6.7 Summary of Chi-squared, Kendal tau and Gamma Test through Cross-tabulation with various nature of Nepal Police \& Armed Police Force

Table 9. Cross tabulation Result on Police officer's Traits

\begin{tabular}{|c|c|c|c|c|c|}
\hline \multirow{2}{*}{$\begin{array}{l}\text { Variables } \\
\text { Alcoholic/Amoral }\end{array}$} & \multicolumn{2}{|c|}{ Nepal Police } & \multicolumn{2}{|c|}{ Armed Police Force } & \multirow[t]{2}{*}{ Cross tabulation Result } \\
\hline & Statistics & p-value & Statistics & p-value & \\
\hline Chi-squared & 909.293 & 0.000 & 600.517 & 0.000 & \multirow{3}{*}{$\begin{array}{l}\text { Significant relation between Alcoholic } \\
\text { and Amoral nature }\end{array}$} \\
\hline Kendal tau & 0.142 & 0.000 & 0.087 & 0.002 & \\
\hline Gamma & 0.177 & 0.000 & 0.109 & 0.002 & \\
\hline Alcoholic/Asocial & Statistics & p-value & Statistics & p-value & \\
\hline Chi-squared & 511.662 & 0.000 & 466.453 & 0.000 & \multirow{3}{*}{$\begin{array}{l}\text { Significant relation between Alcoholic } \\
\text { and Asocial nature }\end{array}$} \\
\hline Kendal tau & 0.084 & 0.002 & 0.161 & 0.000 & \\
\hline Gamma & 0.105 & 0.002 & 0.199 & 0.000 & \\
\hline Alcoholic/Corruption & Statistics & p-value & Statistics & p-value & \multirow{4}{*}{$\begin{array}{l}\text { Significant relation between Alcoholic } \\
\text { and Corruption nature }\end{array}$} \\
\hline Chi-squared & 771.435 & 0.000 & 807.142 & 0.000 & \\
\hline Kendal tau & 0.152 & 0.000 & 0.230 & 0.000 & \\
\hline Gamma & 0.189 & 0.000 & 0.281 & 0.000 & \\
\hline Corruption/Asocial & Statistics & p-value & Statistics & p-value & \\
\hline Chi-squared & 770.190 & 0.000 & 613.606 & 0.000 & \multirow{3}{*}{$\begin{array}{l}\text { Significant relation between Corruption } \\
\text { and Asocial nature }\end{array}$} \\
\hline Kendal tau & 0.203 & 0.000 & 0.110 & 0.000 & \\
\hline Gamma & 0.254 & 0.000 & 0.136 & 0.000 & \\
\hline Age/Alcohol & Statistics & p-value & Statistics & p-value & \multirow{4}{*}{$\begin{array}{l}\text { Not Significant relation between Age } \\
\text { and Alcohol nature }\end{array}$} \\
\hline Chi-squared & 35.493 & 0.225 & 40.628 & 0.093 & \\
\hline Kendal tau & -0.002 & 0.945 & 0.020 & 0.437 & \\
\hline Gamma & -0.002 & 0.945 & 0.025 & 0.437 & \\
\hline Designation/Alcohol & Statistics & p-value & Statistics & p-value & \\
\hline Chi-squared & 51.324 & 0.001 & 42.228 & 0.017 & \multirow{3}{*}{$\begin{array}{l}\text { Not Significant relation between } \\
\text { Designation and Alcohol nature }\end{array}$} \\
\hline Kendal tau & 0.027 & 0.296 & -0.023 & 0.348 & \\
\hline Gamma & 0.038 & 0.296 & -0.033 & 0.348 & \\
\hline
\end{tabular}


The table 9 summarizes the alcoholic behavior of police officer with social approval from respondents. Public does not like alcoholic, corrupt, asocial and amoral behaviors of police administrators. The test indicates that if a police administrator is alcoholic there are significant likelihood towards corruption, amoral, and asocial behaviors.

\subsection{Existing transformational leadership behaviors of Nepalese Police officers in the '5Is' behaviors tools of Bass \& Avolio}

In modern era traits theory was reformed as a transformational leadership theory. In this academic research Bass and Avolio (1994)'s '5Is' are tested to examine the prevailing transformational status of Nepalese Police officers in the survey questionnaire with few modification adding the Likert's 5 scale rating (Table 3 ) in each variables and sub variables. The results are presented in Table 10 and 11.

Table 10. Status of '5Is' Transformation Behaviors of Nepalese Police Officers

\begin{tabular}{llllllll}
\hline Behaviors Style 5 I & $\begin{array}{l}\text { Missing } \\
\mathbf{\%}\end{array}$ & $\begin{array}{l}\text { Not at all } \\
\mathbf{\%}\end{array}$ & $\begin{array}{l}\text { A little } \\
\mathbf{\%}\end{array}$ & $\begin{array}{l}\text { Moderately } \\
\boldsymbol{\%}\end{array}$ & $\begin{array}{l}\text { Mostly } \\
\boldsymbol{\%}\end{array}$ & $\begin{array}{l}\text { Fully } \\
\boldsymbol{\%}\end{array}$ & \begin{tabular}{l} 
Total \% \\
\hline Idealized Behaviors
\end{tabular} \\
Inspirational Motivation & 0.74 & 09.76 & 34.64 & 24.76 & 24.6 & 5.52 & 100.02 \\
Intellectual Stimulation & 1.02 & 15.89 & 26.04 & 26.51 & 24.87 & 5.67 & 100.00 \\
Individualized Consideration & 0.81 & 16.94 & 24.83 & 26.88 & 24.66 & 5.88 & 100.00 \\
Idealized Attributes & 1.64 & 16.06 & 24.28 & 26.39 & 24.86 & 6.77 & 100.00 \\
\hline
\end{tabular}

Source: Field Survey

The table 10 and Figure 3 represents the study carried out on Bass and Avolio (1994)'s "5Is": (1) Individual Behavior, (2) Inspirational Motivation, (3) Intellectual Stimulations, (4) Individualized Consideration Coaching and Development and (5) Idealized Attributes which are applied in examining the behavioral status of Nepalese Police administrators. In this presentation, Idealized Attributes were rated with highest with $32.84 \% ; 22.71 \%$ have rated 'moderately'. Similarly, Individualized Consideration is in second position with 31.63\%; Intellectual Stimulation in third with 31.63\%; Inspirational Motivation in fourth with $30.54 \%$ and Idealized Behaviors in fifth with $30.12 \%$, who have agreed fully and mostly. This indicates that Nepalese police possessed the 'a little towards transformational leadership.

\subsection{Findings on Nepalese Police officers '5IS' behaviors.}

Table 11. Status of Rating on '5Is' Transformational Behaviours of Sub-Variables

\begin{tabular}{|c|c|c|c|c|c|c|c|c|c|c|}
\hline $\begin{array}{l}\mathbf{S} \\
\mathbf{N}\end{array}$ & $\begin{array}{l}\text { Sub Heading of } \\
\text { Behaviors }\end{array}$ & Style of 5 I & $\begin{array}{l}\text { Missin } \\
\text { g \% }\end{array}$ & $\begin{array}{l}\text { Not at } \\
\text { all \% }\end{array}$ & $\begin{array}{l}\text { A little } \\
\%\end{array}$ & $\begin{array}{l}\text { Moderatel } \\
\text { y \% }\end{array}$ & $\begin{array}{l}\text { Mostly } \\
\%\end{array}$ & $\begin{array}{l}\text { Fully } \\
\%\end{array}$ & Mean & $\begin{array}{l}\text { Remark } \\
\text { S }\end{array}$ \\
\hline 1 & $\begin{array}{l}\text { Display a sense of power } \\
\text { and competence }\end{array}$ & $\begin{array}{l}\text { Idealized } \\
\text { Attributes }\end{array}$ & 1.80 & 11.97 & 14.04 & 22.23 & 35.10 & 14.85 & 3.21 & $\begin{array}{l}\text { Moderately } \\
\text { to Mostly }\end{array}$ \\
\hline 2 & $\begin{array}{l}\text { Reassure others that } \\
\text { obstacles will be overcome }\end{array}$ & $\begin{array}{l}\text { Idealized } \\
\text { Attributes }\end{array}$ & 0.99 & 12.06 & 22.32 & 29.97 & 22.95 & 11.70 & 2.97 & Moderately \\
\hline 3 & $\begin{array}{l}\text { Specify the importance of } \\
\text { having a strong sense of } \\
\text { purpose }\end{array}$ & $\begin{array}{l}\text { Idealized } \\
\text { Behaviors }\end{array}$ & 0.54 & 5.94 & 30.51 & 28.62 & 28.98 & 5.40 & 2.96 & Moderately \\
\hline 4 & Promote self-development & $\begin{array}{l}\text { Individualized } \\
\text { Consideration }\end{array}$ & 2.79 & 13.50 & 18.27 & 26.64 & 29.25 & 9.54 & 2.95 & Moderately \\
\hline 5 & $\begin{array}{l}\text { Instill pride in others for } \\
\text { being associated with them }\end{array}$ & $\begin{array}{l}\text { Idealized } \\
\text { Attributes }\end{array}$ & 0.99 & 16.20 & 20.61 & 25.65 & 27.00 & 9.54 & 2.90 & Moderately \\
\hline 6 & $\begin{array}{l}\text { Consider the moral and } \\
\text { ethical consequences of } \\
\text { decisions }\end{array}$ & $\begin{array}{l}\text { Idealized } \\
\text { Behaviors }\end{array}$ & 0.99 & 7.20 & 33.84 & 24.21 & 27.36 & 6.39 & 2.89 & $\begin{array}{l}\text { A little to } \\
\text { Moderately }\end{array}$ \\
\hline 7 & $\begin{array}{l}\text { Seek differing perspectives } \\
\text { when solving problems }\end{array}$ & $\begin{array}{l}\text { Intellectual } \\
\text { Stimulation }\end{array}$ & 0.81 & 15.39 & 18.99 & 30.60 & 28.71 & 5.49 & 2.87 & $\begin{array}{l}\text { A little to } \\
\text { Moderately }\end{array}$ \\
\hline 8 & $\begin{array}{l}\text { Talk enthusiastically about } \\
\text { what needs to be } \\
\text { accomplished }\end{array}$ & $\begin{array}{l}\text { Inspirational } \\
\text { Motivation }\end{array}$ & 0.72 & 13.77 & 23.67 & 27.18 & 29.16 & 5.49 & 2.87 & $\begin{array}{l}\text { A little to } \\
\text { Moderately }\end{array}$ \\
\hline 9 & $\begin{array}{l}\text { Talk optimistically about } \\
\text { the future }\end{array}$ & $\begin{array}{l}\text { Inspirational } \\
\text { Motivation }\end{array}$ & 0.99 & 15.57 & 22.32 & 26.64 & 28.89 & 5.58 & 2.84 & $\begin{array}{l}\text { A little to } \\
\text { Moderately }\end{array}$ \\
\hline 10 & $\begin{array}{l}\text { Express confidence that } \\
\text { goals will be achieved }\end{array}$ & $\begin{array}{l}\text { Inspirational } \\
\text { Motivation }\end{array}$ & 1.17 & 14.76 & 24.30 & 26.91 & 25.92 & 6.93 & 2.82 & $\begin{array}{l}\text { A little to } \\
\text { Moderately }\end{array}$ \\
\hline 11 & $\begin{array}{l}\text { Champion exciting new } \\
\text { possibilities }\end{array}$ & $\begin{array}{l}\text { Idealized } \\
\text { Behaviors }\end{array}$ & 0.81 & 6.93 & 37.71 & 26.46 & 22.23 & 5.85 & 2.80 & $\begin{array}{l}\text { A little to } \\
\text { Moderately }\end{array}$ \\
\hline 12 & $\begin{array}{l}\text { Treat others as individuals } \\
\text { rather than just as members } \\
\text { of the group }\end{array}$ & $\begin{array}{l}\text { Individualized } \\
\text { Consideration }\end{array}$ & 0.72 & 16.02 & 24.66 & 29.34 & 23.94 & 5.31 & 2.76 & $\begin{array}{l}\text { A little to } \\
\text { Moderately }\end{array}$ \\
\hline 13 & $\begin{array}{l}\text { Provide an exciting image } \\
\text { of what is essential to } \\
\text { consider }\end{array}$ & $\begin{array}{l}\text { Inspirational } \\
\text { Motivation }\end{array}$ & 0.90 & 17.37 & 23.85 & 27.27 & 24.66 & 5.94 & 2.75 & $\begin{array}{l}\text { A little to } \\
\text { Moderately }\end{array}$ \\
\hline
\end{tabular}




\begin{tabular}{|c|c|c|c|c|c|c|c|c|c|c|}
\hline 14 & $\begin{array}{l}\text { Encourage non-traditional } \\
\text { thinking to deal with } \\
\text { traditional problems }\end{array}$ & $\begin{array}{l}\text { Intellectual } \\
\text { Stimulation }\end{array}$ & 1.17 & 16.38 & 24.48 & 28.35 & 23.49 & 6.12 & 2.75 & $\begin{array}{l}\text { A little to } \\
\text { Moderately }\end{array}$ \\
\hline 15 & $\begin{array}{l}\text { Encourage rethinking those } \\
\text { ideas which have never } \\
\text { been questioned before }\end{array}$ & $\begin{array}{l}\text { Intellectual } \\
\text { Stimulation }\end{array}$ & 0.81 & 15.84 & 25.20 & 29.88 & 22.50 & 5.76 & 2.75 & $\begin{array}{l}\text { A little to } \\
\text { Moderately }\end{array}$ \\
\hline 16 & $\begin{array}{l}\text { Spend time teaching and } \\
\text { coaching }\end{array}$ & $\begin{array}{l}\text { Individualized } \\
\text { Consideration }\end{array}$ & 2.88 & 15.93 & 21.24 & 29.34 & 25.11 & 5.49 & 2.74 & $\begin{array}{l}\text { A little to } \\
\text { Moderately }\end{array}$ \\
\hline 17 & $\begin{array}{l}\text { Get others to look at } \\
\text { problems from many } \\
\text { different angles }\end{array}$ & $\begin{array}{l}\text { Intellectual } \\
\text { Stimulation }\end{array}$ & 0.81 & 16.92 & 26.82 & 25.02 & 23.49 & 6.93 & 2.74 & $\begin{array}{l}\text { A little to } \\
\text { Moderately }\end{array}$ \\
\hline 18 & $\begin{array}{l}\text { Talk about their most } \\
\text { important values and } \\
\text { beliefs }\end{array}$ & $\begin{array}{l}\text { Idealized } \\
\text { Behaviors }\end{array}$ & 0.54 & 13.50 & 32.58 & 24.03 & 24.12 & 5.22 & 2.73 & $\begin{array}{l}\text { A little to } \\
\text { Moderately }\end{array}$ \\
\hline 19 & $\begin{array}{l}\text { Articulate a compelling } \\
\text { vision of the future }\end{array}$ & $\begin{array}{l}\text { Inspirational } \\
\text { Motivation }\end{array}$ & 0.81 & 16.47 & 27.36 & 25.92 & 23.13 & 6.30 & 2.73 & $\begin{array}{l}\text { A little to } \\
\text { Moderately }\end{array}$ \\
\hline 20 & $\begin{array}{l}\text { Re-examine critical } \\
\text { assumptions to questions to } \\
\text { question whether they are } \\
\text { appropriate }\end{array}$ & $\begin{array}{l}\text { Intellectual } \\
\text { Stimulation }\end{array}$ & 0.63 & 16.74 & 25.92 & 29.61 & 21.69 & 5.40 & 2.71 & $\begin{array}{l}\text { A little to } \\
\text { Moderately }\end{array}$ \\
\hline 21 & $\begin{array}{l}\text { Help others to develop their } \\
\text { strengths }\end{array}$ & $\begin{array}{l}\text { Individualized } \\
\text { Consideration }\end{array}$ & 1.08 & 17.01 & 28.98 & 22.50 & 23.40 & 7.02 & 2.71 & $\begin{array}{l}\text { A little to } \\
\text { Moderately }\end{array}$ \\
\hline 22 & $\begin{array}{l}\text { Listen attentively to others } \\
\text { concerns }\end{array}$ & $\begin{array}{l}\text { Individualized } \\
\text { Consideration }\end{array}$ & 0.72 & 17.82 & 28.26 & 24.12 & 22.59 & 6.48 & 2.69 & $\begin{array}{l}\text { A little to } \\
\text { Moderately }\end{array}$ \\
\hline 23 & $\begin{array}{l}\text { Suggest new ways of } \\
\text { looking at how to complete } \\
\text { assignments }\end{array}$ & $\begin{array}{l}\text { Intellectual } \\
\text { Stimulation }\end{array}$ & 0.63 & 20.34 & 27.54 & 17.82 & 28.08 & 5.58 & 2.69 & $\begin{array}{l}\text { A little to } \\
\text { Moderately }\end{array}$ \\
\hline 24 & $\begin{array}{l}\text { Go beyond their self- } \\
\text { interests for the good for } \\
\text { the group }\end{array}$ & $\begin{array}{l}\text { Idealized } \\
\text { Attributes }\end{array}$ & 0.90 & 19.17 & 30.69 & 20.79 & 19.80 & 8.64 & 2.65 & $\begin{array}{l}\text { A little to } \\
\text { Moderately }\end{array}$ \\
\hline 25 & $\begin{array}{l}\text { Act in ways that build } \\
\text { others respect }\end{array}$ & $\begin{array}{l}\text { Idealized } \\
\text { Attributes }\end{array}$ & 1.44 & 18.27 & 30.24 & 22.68 & 20.88 & 6.48 & 2.63 & $\begin{array}{l}\text { A little to } \\
\text { Moderately }\end{array}$ \\
\hline 26 & $\begin{array}{l}\text { Talk about the importance } \\
\text { of trusting each other }\end{array}$ & $\begin{array}{l}\text { Idealized } \\
\text { Behaviors }\end{array}$ & 0.81 & 15.21 & 38.52 & 20.43 & 20.25 & 4.77 & 2.58 & $\begin{array}{l}\text { A little to } \\
\text { Moderately }\end{array}$ \\
\hline 27 & $\begin{array}{l}\text { Take a stand on } \\
\text { controversial issues }\end{array}$ & $\begin{array}{l}\text { Inspirational } \\
\text { Motivation }\end{array}$ & 1.53 & 17.37 & 34.74 & 25.11 & 17.46 & 3.78 & 2.51 & $\begin{array}{l}\text { A little to } \\
\text { Moderately }\end{array}$ \\
\hline 28 & $\begin{array}{l}\text { Make personal sacrifices } \\
\text { for others benefit }\end{array}$ & $\begin{array}{l}\text { Idealized } \\
\text { Attributes }\end{array}$ & 0.81 & 27.18 & 36.99 & 14.94 & 12.87 & 7.20 & 2.33 & $\begin{array}{l}\text { A little to } \\
\text { Moderately }\end{array}$ \\
\hline
\end{tabular}

\section{Source: Field survey}

The result prevailed in Table 11 the literature so far found in the studies has thrown light on leadership and police administration. However, they have not come to the status, and efficiency of police administration and police leadership relating to how they should be responding towards the existing complicated situation. The respondents have not fully agreed but moderately to mostly agreed. The survey shows people are somehow comfortable with police administration. Almost variable were rated by the respondents 'a little to moderately'. It shows the police officers possessed average rating. Only the variable "Displays a sense of power and competence" is rated with the mean value 3.21 among the 28 variables. People do not like leadership based on traits, where police officers were evaluated with near to average rating in each group. But they are in favor of adaptation of transformational leadership style in policing. A comprehensive effort is needed for better ethical and transformational leadership. These "5Is" have great potential to promote performance beyond expectations and to affect enormous changes within individuals and organizations especially in security forces of a democratic country at current times characterized by uncertainty and instability in organizational, national, regional and global levels in terms of socio-economy and resource allocation and distribution, which have direct and indirect relation with security as a whole.

\subsection{Findings on effecting elements for the development of police officers in Nepal}

Table 12. Effective Elements for the Development of Police leadership

\begin{tabular}{|c|c|c|c|c|c|c|c|c|}
\hline $\begin{array}{l}\text { S. } \\
\text { N. }\end{array}$ & Effecting Elements & $\begin{array}{l}\text { Missing } \\
\%\end{array}$ & $\begin{array}{l}\text { Strongly } \\
\text { Disagree } \\
\% \\
\end{array}$ & $\begin{array}{l}\text { Disagree } \\
\%\end{array}$ & $\begin{array}{l}\text { Neutral } \\
\%\end{array}$ & $\begin{array}{l}\text { Agree } \\
\%\end{array}$ & $\begin{array}{l}\text { Strongly } \\
\text { Agree \% }\end{array}$ & Mean \\
\hline 1. & Professional Trainings & 0.63 & 0.00 & 3.42 & 27.63 & 46.44 & 21.87 & 3.85 \\
\hline 2. & Act \& Regulation & 0.54 & 3.24 & 10.62 & 14.58 & 53.83 & 17.19 & 3.69 \\
\hline 3. & $\begin{array}{l}\text { Officer's Professional Integrity } \\
\text { towards Service Himself }\end{array}$ & 0.63 & 1.98 & 8.01 & 30.06 & 37.17 & 22.14 & 3.68 \\
\hline 4. & Challenging Job & 0.45 & 1.53 & 7.29 & 28.26 & 48.87 & 13.59 & 3.64 \\
\hline 5. & Respect \& Recognition of Talent & 0.63 & 1.17 & 12.06 & 28.62 & 34.83 & 22.68 & 3.64 \\
\hline 6. & Fair Competition \& Evaluation & 0.54 & 4.05 & 14.85 & 21.33 & 31.95 & 27.27 & 3.62 \\
\hline 7. & Educational Level & 0.45 & 1.71 & 8.64 & 29.97 & 43.47 & 15.75 & 3.62 \\
\hline
\end{tabular}




\begin{tabular}{|c|c|c|c|c|c|c|c|c|}
\hline 8. & Charismatic leader Situation & 0.72 & 6.03 & 7.38 & 22.50 & 43.83 & 19.53 & 3.61 \\
\hline 9. & Field Experience & 0.99 & 1.62 & 12.15 & 26.64 & 42.21 & 16.38 & 3.57 \\
\hline 10. & $\begin{array}{l}\text { Division of Labor, Decentralization } \\
\& \text { Accountability }\end{array}$ & 0.63 & 1.53 & 8.01 & 34.38 & 42.12 & 13.32 & 3.56 \\
\hline 11. & $\begin{array}{l}\text { Positive Role \& Attitude of } \\
\text { Supervisor }\end{array}$ & 0.81 & 1.98 & 11.88 & 28.44 & 40.32 & 16.56 & 3.55 \\
\hline 12. & $\begin{array}{l}\text { Enthusiasm/Attraction towards } \\
\text { Service }\end{array}$ & 0.81 & 1.62 & 10.53 & 33.75 & 37.80 & 15.48 & 3.53 \\
\hline 13. & Organizational Grooming & 0.72 & 1.53 & 12.96 & 31.77 & 37.17 & 15.84 & 3.51 \\
\hline 14. & $\begin{array}{l}\text { Positive Attitude of Subordinate \& } \\
\text { Staffs }\end{array}$ & 1.08 & 1.71 & 13.41 & 30.42 & 37.17 & 16.20 & 3.50 \\
\hline 15. & Career Development & 0.63 & 2.16 & 10.71 & 37.53 & 36.27 & 12.69 & 3.45 \\
\hline 16. & The Role of Time, Place \& Situation & 0.99 & 2.43 & 11.79 & 34.47 & 38.88 & 11.43 & 3.42 \\
\hline 17. & Blessing from Political Power Centre & 0.63 & 15.75 & 11.34 & 6.48 & 45.00 & 20.79 & 3.42 \\
\hline 18. & Money & 0.54 & 14.85 & 9.27 & 9.54 & 49.77 & 16.02 & 3.41 \\
\hline 19. & Organizational Behavioral Culture & 0.90 & 1.98 & 12.42 & 37.17 & 37.98 & 9.54 & 3.38 \\
\hline 20. & Job Security & 0.54 & 6.84 & 12.87 & 35.73 & 33.57 & 10.44 & 3.26 \\
\hline 21. & $\begin{array}{l}\text { Inspired by previous philosophy and } \\
\text { role mod }\end{array}$ & 0.72 & 3.60 & 18.09 & 39.96 & 31.14 & 6.48 & 3.17 \\
\hline 22. & Socio-Culture Background & 0.54 & 4.23 & 17.64 & 43.56 & 28.26 & 5.76 & 3.12 \\
\hline 23. & Luck & 0.72 & 21.78 & 28.17 & 24.03 & 21.42 & 3.87 & 2.55 \\
\hline 24. & By birth & 0.90 & 23.22 & 34.83 & 26.55 & 10.62 & 3.87 & 2.34 \\
\hline
\end{tabular}

\section{Source: Field Survey}

In the table 12 the results represent 1. Professional trainings (3.85); 2. Act \& regulation (69); 3. Officer's professional integrity towards service himself (3. 68); 4. a Challenging job (3.64); 4.b Respect and recognition of talent (3.64), 5.a Fair competition and evaluation(3.62); 5.b Educational level(3.62); 6. Charismatic leadership situation (3.61) and 7. Field experience (3.57), which are seven highest rated elements. Their role should be crucial in the development of police leadership in the country. The survey result also indicates that police leadership development should not be affected by birth, luck, money and blessing from political party.

\section{Findings from Interviews}

Twenty one veteran intellectuals, administrative and security executives who took part in this study as in-depth interviewees are part of a diverse personality in terms of their expertise, experience and effective potentiality regarding this research. In the interview, a total of 21 (mail 19 and 2 female) veterans were targeted on the basis of their proven talent in respective fields and expertise. Their insights, ideas, views and perceptions are presented as a collective basket of firmed experience and ground realities.

Most of the respondents expressed their perception and views on police leadership development that system is not stable and firmed. 'Yes-man' attitude has increased in the country since the restoration of democracy in 1990 and mushrooming with the beginning of the post conflict transitional status in the country. A few became the double edged agents to take the undue advantage of transitional status of the country. They had emphasized that youth leaders must have forsaken their logical visualizations, instead of being a silent watcher on a mute "Yes-man" attitude. Promotions of the incompetent and wrong people who were not fit for the rank and mandates they held. Professionalism, values and norms of the security forces have been superseded by unprofessionalism and unethical politicization for personal benefits. Professional executives and commanders have been placed under the command-ship of untrained and nonprofessional personalities who were not developed nor converted but inverted with the interest of a few senior leaders' private interest and benefits. Surprisingly, the most leaders have common interest towards earning money by hook or by crook.

Some had uttered to develop and enhance capabilities of the national army for its dual roles of dealing with both conventional and low-intensity military and insurgency. Furthermore, national veterans and intellectuals are not honored and used properly. If incompetent and unprofessional personnel get to the senior executive position, he/she knells down before the political power and becomes hesitant before them. Such sycophant executive cannot work for the sake of organization. As a result of the leaderships, whole institution and the nation become weaker.

Leaders live in glass house where all activities are observed by their peers, subordinates and staffs. The party politicization and security -crime nexus must not be encouraged. Instead of statesmanship, clan dominating system and external intervention may increase social unrest, class conflict and poverty-gap and country will be pushed towards a failed state. It can be harmful in national, regional and global security arenas gradually.

Furthermore, men/women in uniform and veterans should not be compared with other services. Their dependent family members must provide the basic needs to enable them a dignified living in community, so that they will not shake hands with 'Gundas' (hooligans), smugglers, and criminals. Most respondents were univocal that exception always may take place, but the lesson learned from the past should be assured and corrected timely for better execution in present in 
visualizing the future needs and threats. A just smooth careerism with the values, norms and needs of organization may lead the whole organization to accomplish the mandated missions efficiently with a high morale. The system based leadership career development strategy should be adopted in copying the people's expectation and meeting the needs of the organization.

8. Findings on comparative average tenure of key heads of the government and police administrations, based on secondary data

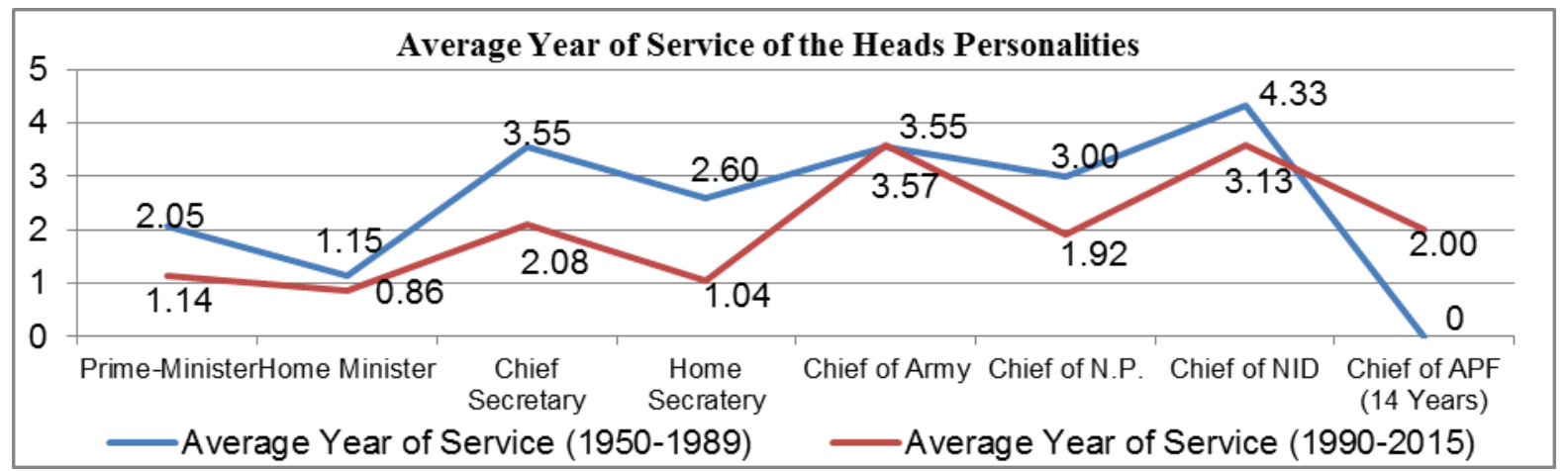

Figure 3. Average year of service

Source: compiled from secondary data

The table pertaining to Figure 3 is shown in ANNEX VI. Figure 3 is displaying the situation that how the police administration was evaluated by the people. It shows the period of before restoration of democracy and after the restoration of democracy and the comparison of the two periods found no significant difference. This is revealed in the frequent change on the top police leadership in the role of Prime minister, Home Minister, Chief Secretary, Home Secretary, Chief of Nepal Police (NP), Chief of Armed Police Force (APF) and Chief of National Investigation Department (NID).

The observation of police leadership from last 65 years shows frequent changes in a short period of time. The period can be divided into two types of political systems. The previous is party less kingship political system (1950 to 1990) and second is multiparty kingless political system (1990 to June, 2015). In the comparison of secondary data of the key heads of the government and national security administration, it can be visualized that in part one where highest average tenure was 4.33 years for chief of National Investigation department, whereas 3.57 years were for both Chief of Army and chief of Investigation Department in part two. In comparison between parts one and two almost all heads' average tenure are decreased except Chief of Army which remains moderately stable.

The average service tenure for Chief of NP was 3 years in part one, but declining in part two the present average tenure is 1.92 years. The figure only represents the status but the concern of all executive levels the situation is huge and alarming. Since the last decades, the scenario is worsening and the situation may prevail hopeless and imbalanced in the days ahead if visionary leadership development career plan and evaluation system may not be introduced in national security administration. It is experienced that the scenario is expensive whereas professional quality and output are superficial and unsteady. Meanwhile, 30 year service tenure is symbolized 'BLACK DAY' in NP and NID and the same applies in APF. Since the execution of this system almost 12 Chiefs have been retired in NP. In APF the system was imposed in 2009 and 4 Chiefs were retired by 2012 and a technician without the security trainings and command is in vital position who was enrolled for the architect engineer service who was appointed in the crucial role and responsibility by Maoist led government in 2012 .

The post of heads and executives are being economically unproductive, professionally valueless and no accountability, and physically and personally ceremonial. Furthermore, newly appointed top executives need time for socialization and orientation. The study shows that when they become socialized before execution of the security policies and strategies, they become terminated or replaced. The same cycle repeats in the cases of top brass security executives. Effectiveness in operation of delivering of public services of people depends on the tenure of administrators; studies frequently change in administration, and political systems have differentiated the delivering system of service, safety and security of the people. Research concluded that senior executives spend their time and days not in security research, planning and administration but in socialization and personal networking. There is no stability in security administration. Security sector's re-engineering and development is the prime need for lasting peace, and reliable security and sustainable development of the nation.

30 years' service tenure, politicization in promotion of police executives, poor professionalism, ceremonial leadership development tendency, bad money matter, 'Yes-men' attitude in police leaderships and external pressure are major lapses and negligence from the senior leaders are the root cause and consequences for weakening security and harassment to the police leaderships. This is the emerging challenge against democratic norms, values and notion in the country. Ultimately, people and country have had to suffer. Thus, police administration should be focused to develop and prepare the police and police leaderships with the pace of shifting paradigm from sate centric approach towards the human centric with long-term vision and comprehensive strategies. The police executives are required to have a high level of ethical commitment not only as job or profession. Police leaderships should apply the self-actualization for the 
betterment and trustworthy image of services. They must dare to convince political leaders and people to be aware for securities from any types of threats.

Since the last few years, the decision taken by respective government has been challenging in the court by police officers and personnel. On the other hand, the order realized by the Supreme Court is not being implemented. On 24th September, 2014 in Certioraryfied Mandamus Write Petition of Writ No. 071-WO-0078 of the year 2014 the Supreme Court ordered to promote and appoint the victims/ petitioners: Deputy Inspector Generals of Nepal Police: Yadav Adhikari, Parshuram Kharti, Sushilbar Singh Thapa, and Bishworaj Singh Shahi in the post of Additional Inspector General of Nepal Police if there are vacant else create the posts for them. On December 8th, 2014 the Supreme Court Judgment Execution Directorate followed execution and re-ordered to the concern agencies about the execution of the order but not implemented. Similarly, a series of writ on 'Contempt' are against the decision taken by armed police authorities. Writ no 1305 forced deployment (Petitioner Assistant Head Constable Indra Bahadur Pubachhane Magar), writ no 1305 "Contempt', Writ no 069 WO 1428 and 0269 case against illegal transfer and replacement (petitioner Deputy Superintendent Engineer Naniram Humagain) represents merging cases in APF. However, a series of examples are there that most of them are not knocking the door of the court and does not mean that decisions are fair, acceptable and ethical. These are only few indications for injustice and lack of faith in commanders and police administrations.

\section{Conclusion}

The police service today is much more scientific, professional, and bounded with legal and moral accountability. Unethical decisions taken by anyone, anytime and anywhere is wrong. Avoiding the conflict, tolerating the humiliation and injustice, not registering the case in court are weaknesses of democratic government and should not be underrated any more. This is the sum of professionalism, if the truth fails with conspiracy and no one thinks to be accountable, leadership would not be a position in ethical policing in real democratic notion in any country. Leading from front is essential in security forces of developing country like Nepal. A democratic developing country needs to develop police organizations making them capable to respond the changing paradigms. On the other hand, professionalism, values and norms have been superseded by unprofessionalism. They tune their lips in the matter of money making game. The drives of change could be values based on 'intelligence-led policing' followed by public partnership'(Shrestha, 2015) and 'transformational leaderships' followed by participative/ democratic, authentic and strategic models. Additionally, the study also indicates that professionalism values and norms should not be suppressed by unprofessionalism, and the leadership development should not be affected by blessing from political party and money. Due to the poor and inefficient leadership as discussed, the police administrations have to be able to deliver the professionals needed by the community and nation. Therefore, it is essential that both police services must be revitalized so that delivery to the people and nation can be ensured and the country is welfare-state. Leadership should be bounded by 'RARA': Role, Responsibility, Resources and Accountability. The universal values, norms and legal procedures can be the tools to tighten the national security forces in federal democratic notion of the country. If the truth is bitter, let us swallow it is bitter to cure the maladies timely.

\section{Acknowledgement}

Sincere gratitude and hearty salutation to all respondents, research supervisors and mentors Prof. Dr. Anant Lal Karan, Prof. Dr, Sateesh K. Ojha, Shivram Pandey, Dr. Shiv Ram Dhakal, Dr. Chuda B. Shrestha, Dr. Yushodhama Tripati, Dr. Indrajit Rai, former Chief of National Investigation Department Mr. Deviram Sharma, Dr. Khagendra Ojha, Engineer Bhavesh Shrestha for their valuable guidelines, and inspirations in this academic research. My sincere salutation to the Singhania University Rajasthan, India for providing the opportunity and supervision. In addition, I am grateful for insightful suggestions and supervision provided by their reviewers for JIELS publication. Finally, my hearty gratitude to Mr. Narendra Pokhara, Mr. Rajan Budhathoki and the core family members, relatives; for their immense support, cooperation and understanding.

\section{Reference}

Baba, S.S. (1993). Love and leadership. In Saiba's Mahavakya on leadership. Chibber M.L.(1999). Sri Sathya Sai Books and Publications Trust, India. ISBN- 81-7208-180-4.

Baral, L. R., Hachhethu, K. \& Sharma H. (2001). Leadership in Nepal (A pilot study). Nepal

Centre for Contemporary Studies in Cooperation of the Embassy of Finland, Kathmandu Nepal. ISBN 81-87392-23-1

Bass, B.M. (1990). From transactional to transformational leadership: Learning to share the vision. Organizational Dynamics, 18 (3), 19-31.

Bass, B. M. (2008). The Handbook of Leadership Part A. New York: Free Press.

Bass, B.M.\& Avolio, B.J. (1994) Improving organizational effectiveness through transformational leadership. Thousand Oaks, CA: Sage Publications

Bhattarai, R. (2010). Broadening Nepal's security agenda: armed conflcit, migration and environmental perspectives. In R. B. Wagle (Ed.), Emergency Security Challenges of Nepal. Kathmandu, Nepal: Nepal Institute for Polciy Studies.

Brahma Kumaries. (n.d.). www.brahmakumaris.org. (B. K. University, Producer) Retrieved June 6th, 2015, from Brahma Kumaries: http://www.brahmakumaris.org/whoweare/brahmababa.htm

Burns, J.M. (1978). Leadership. New York: Harper \& Row. 
Chibber, M.L. (1999). Saiba's mahavakya on leadership. Sathya Sai Books and Publications Trust, India. ISBN- 817208-180-4.

Covey, S. (2007, Sep. 23). Leadership Development . (S. Khan, Interviewer)

Creswell, J. W. (2009). Reserach design-qualitative, quantitative, and mixed methods approaches 6th printing 2012 (3rd ed.). New Delhi: Vivek Mehara SAGE Publications India Pvt Ltd.

David V. Day\& Jhon Antonakis (Ed.), (2012). The Nature of Leadership 2nd Edition, edited by SAGE publication. Figure 1.1, Page 7.

Dobby, J., Anscombe, J. and Tuffin, R. (2004) 'Police leadership: expectations and impact', London: Home Office Online Report 20/04.

Dolezalek, H. (2005). Industry Report. Training , 42, 14-28

Janet A. Simons, D. B. (1987). web.archive.org. (I. A. Machine, Producer) Retrieved April 30th, 2015, from Internate Archive

https://web.archive.org/web/20100211014419/http://honolulu.hawaii.edu/intranet/committees/FacDevCom/guidebk/tea chtip/maslow.htm

Jim Isenberg, P. (2010). Police leaderhip in a democracy. Taylor and Francis Group, LLC.

Kalam, A. R. (2006). Inaguration speech. In N. The global Open University, Police Reform Part-2 (2008) M. Phil in Police Administration Self Instruction Material. The global Open University, Nagaland.

K.C., B. B. (2014, May 14). http://www.tinepal.org. Retrieved from Transparency International Nepal:

http://www.tinepal.org/tmp-content/uploads/2014/05/2014_NISNepal_EN.pdf

Litchtheim, M. (1973). Ancient Egyptian Literature: The Old and Middle Kingdoms. University of California Press.

Khatiwada, Y. R. (2014, March 27). Cooperatives, Economic Democracy and Human Security: Perspectives from Nepal. Retrieved from Nepal Rastra Bank: http://www.nrb.org.np/ofg/events_ofg/Governor's_SpeechesGovernor's_Presentation_Paper_at_1st_National_Cooperative_Congress_a.pdf

Lord, R.G., Devader, C.L., and Alliger, G.M. (1986) A meta-analysis of the relation between personality traits and leadership perception: An application validity generalization procedures. Journal of Applied Psychology, 71,402-410

Matt Tomlinson; Wendy Smith; Lenore Manderson (2012). "4. Brahma Kumaris: Purity and the Globalization of Faith". Flows of Faith: Religious Reach and Community in Asia and Pacific. Springer Science + Business Media. HYPERLINK "http://en.wikipedia.org/wiki/International_Standard_Book_Number" lo "International Standard Book Number" ISBN HYPERLINK "http://en.wikipedia.org/wiki/Special:BookSources/978-94-007-2931-5" lo "Special:BookSources/978-94-007-2931-5" 978-94-007-2931-5 .

MeeseIII, P.J. Ortmeier \& Edwin (2010). Leadership, Ethics, and Policing- challenges for the 21st Century 2nd edition. New Jersy: Pearson Prentice Hall.

Melton, J. Gordon; Baumann, Martin (2010). Religions of the World. A Comprehensive Encyclopedia of Beliefs and Practices. ABC-CLEO, LLC. $\quad$ pp. 383-384. "http://en.wikipedia.org/wiki/International_Standard_Book_Number" lo "International Standard Book Number" ISBN HYPERLINK "http://en.wikipedia.org/wiki/Special:BookSources/9781576072233" lo "Special:BookSources/9781576072233" 9781576072233

Mills, D. Q. (2005). Retrieved April 30th, 2015, from http://www.cafanet.com/LinkClick.aspx?fileticket=qwswE8roe74\%3D\&tabid=96

Modi, N. (2014). Text of prime minister Shri Narendra Modi's Speech at All India Conference of Director Generals/Inspector Generals of Police at Guwahati. Retrieved April 22nd, 2015, from http://www.narendramodi.in/textof-prime-minister-shri-narendra-modis-speech-at-all-india-conference-of-directorgeneralsinspector-generals-of-policeat-guwahati/

Moran, B. (1992). Library trend.. 40(3), 377-80. Retrieved from https://www.ideals.illinois.edu/bitstream/handle/2142/7786/librarytrendsv40i3b_opt.pdf?sequence=1

Nepal Police. (n.d.). http://www.nepalpolice.gov.np/. Retrieved May 30, 2015, from Nepal Police: http://www.nepalpolice.gov.np/women-children-service-directorate.html

Nepalese Army. (n.d.). http://www.nepalarmy.mil.np/. (N. Army, Producer) Retrieved May 30, 2015, from Nepalese Army: http://www.nepalarmy.mil.np/wia.php

Puig, E. (2012, September 27). http://www.iss.europa.eu/. Retrieved April 30th, 2015, from European Union Institute for Security Studies: http://www.iss.europa.eu/publications/detail/article/the-importance-of-domestic-securityapparatus-in-chinas-leadership-transition/

Rai, I. (2006). Human Security:poverty alleviation, education and halth services(A Nepal Perspective) in baral, L(ed), Non-Traditonal Secuirty, State, society and Democracy in south Asia. New Delhi: Adroit.

Roberson, M. L. (2007). Policing today and tomorrow. Upper Saddle River, , New Jersey 07458, USA: Pearson Education, Inc. 
Salas, E. and Cannon-Bowers, J.A. (2001). The Science of Training: A Decade of Progress. Annual Review of Psychology , 52, 471-99.

Security Sector Agency Modernization High-level Action Committee Report - unpublished (2012).

Sharma Wagle, G. (2010). New challenges for National Security in the changed Context: armed conflcit, migration and environmental perspectives. In R. B. Wagle (Ed.), Emergency Security Challenges of Nepal. Kathmandu, Nepal: Nepal Institute for Polciy Studies.

Shrestha, C. B. (2004). Nepal coping with maoist insurgency-conflict analysis and resolution. Kathmandu: ChetanaLokshum.

Shrestha, T. M. (2015). Policing Challenged and people's expectations. International Journal of Education \& Literacy Studies, 3(2). doi:doi:10.7575/aiac.ijels.v.3n.2p.7

Sis. B.K. Usha (2002). Self Managing Leadership. Literature Department, Pandav Bhawan, Mt. Abu.

Stogdill, R. M. (1974).Handbook of leadership (1st Ed.). New York: Free Press.

Swami Vivekanand (ND). Swami Vivekananda-his call to the nation. The General Secretary Ramkrishna Math and Mission May, 2011. West Bengal, India. ISBN-978-81-7505-018-7

Tancredi, N. (2013, July 23). Effective Leadership Practices in Public Safety Organizations Effective Leadership Practices in Public Safety Organizations. Retrieved May 30th, 2015, from http://www.academia.edu/4415415/Effective_Leadership_Practices_in_Public_Safety_Organizations

Tancredi, N. (2013, December). Improving the image and reputation of the security profession. International foundation for protection officer. Retrieved May 30, 2015, from http://www.ifpo.org/wpcontent/uploads/2013/08/Tancredi_Reputation.pdf

Vicere, A. and Fulmer, R. (1996). Leadership by Design. Harvard Business SchoolPress, Boston, MA.

Wren, J.T. (1995). The leader's companion: Insights on leadership through the ages. New York: The Free Press.

Yukl, G. (1989). Managerial leadership: a review of theory and research. Journal of Management 15 (2), pp. $251-89$.

Zaccaro, S. J., Kemp, C., \& Bader, P. (2004). Leader traits and attributes. In J. Antonakis, A. T. Cianciolo, \& R. J. Sternberg (Eds.).The nature of leadership (pp. 101-124). Thousand Oaks, CA: Sage. 


\begin{tabular}{|c|c|c|c|c|c|}
\hline Stogdill & Mann & $\begin{array}{l}\text { Stogdill and } \\
\text { Alliger }\end{array}$ & $\begin{array}{l}\text { Lord De Vader } \\
\text { and Locke }\end{array}$ & $\begin{array}{l}\text { Kirkpatrick } \\
\text { Kemp, and } \\
\text { Bader }\end{array}$ & Zaccaro \\
\hline (1948) & (1959) & (1974) & (1986) & (1991) & $(2004)$ \\
\hline $\begin{array}{l}\text { Intelligence } \\
\text { Alertness } \\
\text { Insight } \\
\text { Responsibility } \\
\text { Initiative } \\
\text { Persistence } \\
\text { Self-confidence } \\
\text { Sociability }\end{array}$ & $\begin{array}{l}\text { Intelligence } \\
\text { Masculinity } \\
\text { Adjustment } \\
\text { Dominance } \\
\text { Extroversion } \\
\text { Conservative }\end{array}$ & $\begin{array}{l}\text { Achievement } \\
\text { Persistence } \\
\text { Insight } \\
\text { Initiative } \\
\text { Self-confidence } \\
\text { Responsibility } \\
\text { Cooperativeness } \\
\text { Tolerance } \\
\text { Influence } \\
\text { Sociability }\end{array}$ & $\begin{array}{l}\text { Intelligence } \\
\text { Masculinity } \\
\text { Dominance }\end{array}$ & $\begin{array}{l}\text { Drive } \\
\text { Motivation } \\
\text { Integrity } \\
\text { Confidence } \\
\text { Cognitive ability } \\
\text { Task Knowledge }\end{array}$ & $\begin{array}{l}\text { Cognitive ability } \\
\text { Extroversion } \\
\text { Conscientiousness } \\
\text { Emotional stability } \\
\text { Openness } \\
\text { Agreeableness } \\
\text { Motivation } \\
\text { Social intelligence } \\
\text { Self-monitoring } \\
\text { Emotional } \\
\text { Problem solving }\end{array}$ \\
\hline
\end{tabular}

Source: Adapted from: The Bass of Social Power," by J. R. P. French, J. R. P. and B. Raven, 1962, in D. Cartwright(Ed.), Group Dynamics: Research and Theory ( pp. 259), New York: Harper and Row; Zaccoro, Kemp, Bader (2004).

\section{ANNEX II}

The Eight Attitudes of Effective Leader

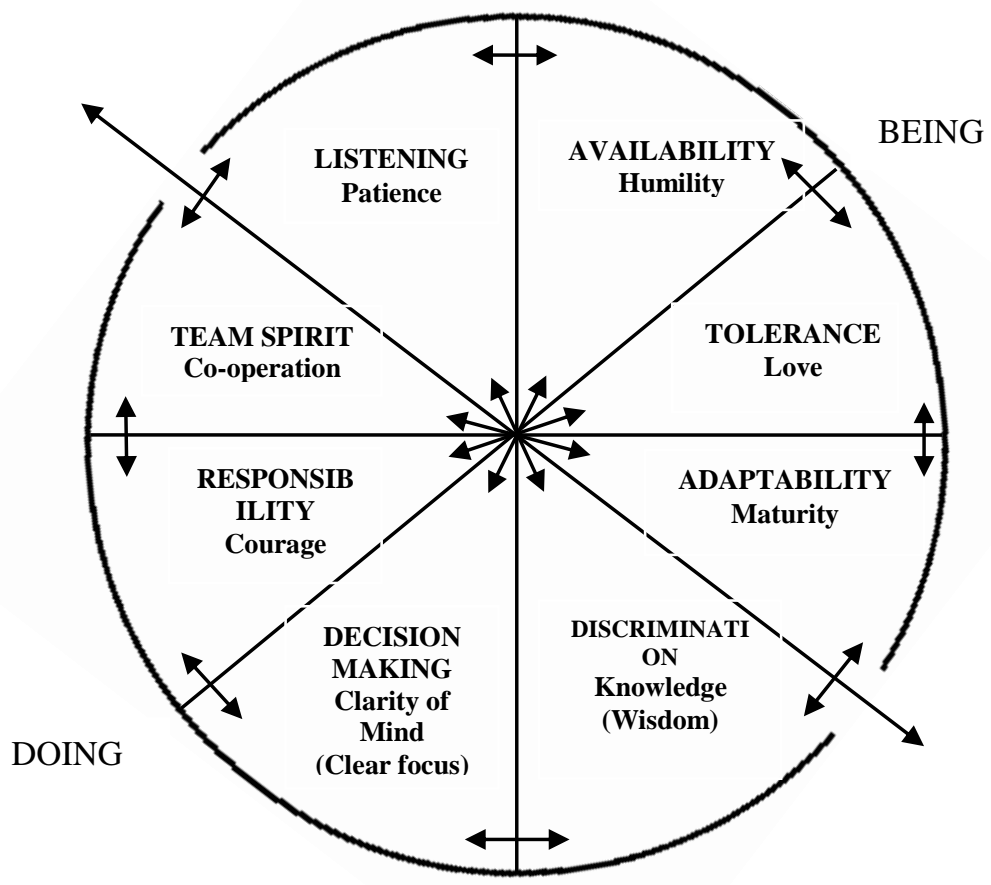

Source: Sis. B.K. Usha (2002). Self Managing Leadership. Literature Department, Pandav Bhawan, Mt. Abu. 


\section{Prevailing Status of Women Personnel in Police forces of Nepal}

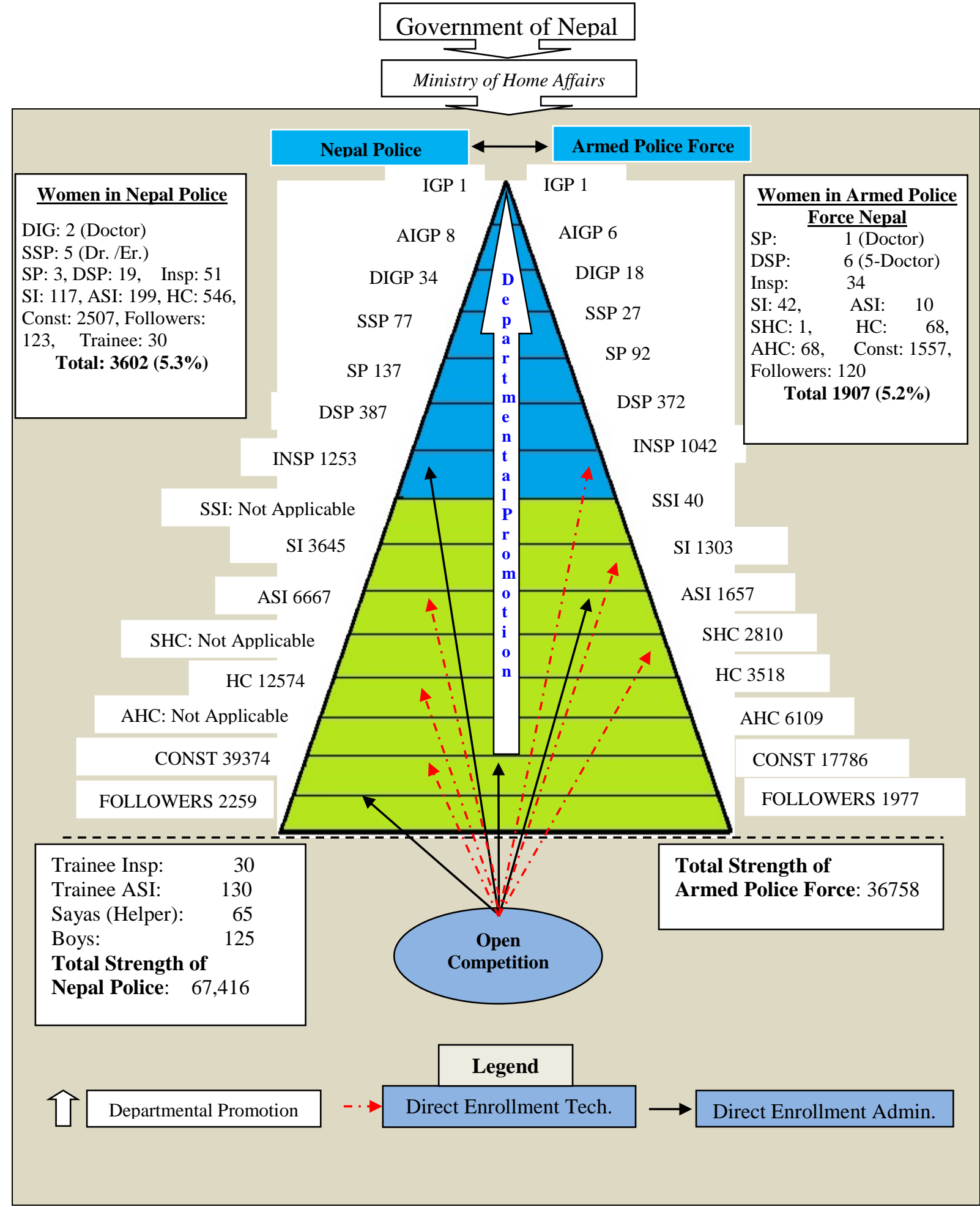

Source: $\quad$ Nepal Police and Armed Police Force HQs. (April, 2015) 
Independent Sample T-Test with Gender

\begin{tabular}{|c|c|c|c|c|c|c|c|}
\hline SN & Leadership Style & & $\mathbf{F}$ & Sig. & $\mathbf{t}$ & df & $\begin{array}{l}\text { Sig. (2- } \\
\text { tailed) }\end{array}$ \\
\hline \multirow[t]{2}{*}{1.} & \multirow{2}{*}{ Authentic } & Equal variances assumed & 6.009 & .014 & 1.453 & 1106 & .147 \\
\hline & & Equal variances not assumed & & & 1.301 & 180.535 & .195 \\
\hline \multirow[t]{2}{*}{2.} & Participative/ & Equal variances assumed & .908 & .341 & -.976 & 1106 & .329 \\
\hline & Democratic & Equal variances not assumed & & & -.952 & 190.029 & .342 \\
\hline \multirow[t]{2}{*}{3.} & \multirow{2}{*}{ Situational } & Equal variances assumed & .006 & .940 & -1.702 & 1106 & .089 \\
\hline & & Equal variances not assumed & & & -1.710 & 194.000 & .089 \\
\hline \multirow[t]{2}{*}{4.} & \multirow{2}{*}{ Strategic } & Equal variances assumed & 2.170 & .141 & .423 & 1106 & .672 \\
\hline & & Equal variances not assumed & & & .408 & 188.718 & .684 \\
\hline \multirow[t]{2}{*}{5.} & \multirow{2}{*}{ Supportive } & Equal variances assumed & .015 & .904 & -1.456 & 1106 & .146 \\
\hline & & Equal variances not assumed & & & -1.448 & 192.688 & .149 \\
\hline \multirow[t]{2}{*}{6.} & \multirow{2}{*}{ Task-Oriented } & Equal variances assumed & 6.042 & .014 & .212 & 1106 & .832 \\
\hline & & Equal variances not assumed & & & .194 & 182.817 & .847 \\
\hline \multirow[t]{2}{*}{7.} & \multirow{2}{*}{ Transformational } & Equal variances assumed & 5.893 & .015 & -1.755 & 1106 & .080 \\
\hline & & Equal variances not assumed & & & -1.661 & 186.491 & .098 \\
\hline
\end{tabular}

Source: Field Survey

One way ANOVA Test with Age, Education, Occupation \& Designation

\begin{tabular}{|c|c|c|c|c|c|c|c|c|c|c|}
\hline \multirow[t]{2}{*}{$\overline{\mathbf{S N}}$} & \multirow[t]{2}{*}{ Leadership Style } & & \multicolumn{2}{|c|}{ AGE } & \multicolumn{2}{|c|}{ EDUCATION } & \multicolumn{2}{|c|}{ OCCUPATION } & \multicolumn{2}{|c|}{ DESIGNATION } \\
\hline & & & $\mathbf{F}$ & Sig. & $\mathbf{F}$ & Sig. & $\mathbf{F}$ & Sig. & $\mathbf{F}$ & Sig. \\
\hline 1. & Authentic & $\begin{array}{l}\text { Between Groups } \\
\text { Within Groups } \\
\text { Total }\end{array}$ & 2.398 & .026 & 1.070 & .379 & 3.999 & .046 & 3.013 & .010 \\
\hline 2. & $\begin{array}{l}\text { Participative/ } \\
\text { Democratic }\end{array}$ & $\begin{array}{l}\text { Between Groups } \\
\text { Within Groups } \\
\text { Total }\end{array}$ & .379 & .893 & 1.638 & .133 & 1.815 & .178 & 2.325 & .041 \\
\hline 3. & Situational & $\begin{array}{l}\text { Between Groups } \\
\text { Within Groups } \\
\text { Total }\end{array}$ & 1.401 & .211 & .258 & .956 & 1.332 & .249 & 2.272 & .045 \\
\hline 4. & Strategic & $\begin{array}{l}\text { Between Groups } \\
\text { Within Groups } \\
\text { Total }\end{array}$ & .959 & .452 & 4.757 & .000 & 10.038 & .002 & 3.047 & .010 \\
\hline 5. & Supportive & $\begin{array}{l}\text { Between Groups } \\
\text { Within Groups } \\
\text { Total }\end{array}$ & .597 & .733 & 1.966 & .068 & 1.583 & .209 & 1.127 & .344 \\
\hline 6. & Task-Oriented & $\begin{array}{l}\text { Between Groups } \\
\text { Within Groups } \\
\text { Total }\end{array}$ & .808 & .564 & 2.321 & .031 & 9.222 & .002 & 4.531 & .000 \\
\hline 7. & Transformational & $\begin{array}{l}\text { Between Groups } \\
\text { Within Groups } \\
\text { Total }\end{array}$ & 1.434 & .198 & .951 & .457 & .120 & .729 & 1.851 & .100 \\
\hline
\end{tabular}

Source: Field Survey

ANNEX: V

Crosstab analysis on of Leadership style in the basis of different demography

Crosstab with Age Group by Leadership Style

\begin{tabular}{|c|c|c|c|c|c|c|c|c|}
\hline \multirow[b]{2}{*}{ S.N. } & \multirow[b]{2}{*}{$\begin{array}{l}\text { Leadership } \\
\text { Style }\end{array}$} & \multirow[b]{2}{*}{ Age Group } & \multicolumn{6}{|c|}{ Rating } \\
\hline & & & $\begin{array}{l}\text { Missing } \\
\%\end{array}$ & $\begin{array}{l}\text { Strongly } \\
\text { disagree } \\
\% \\
\end{array}$ & $\begin{array}{l}\text { Disagree } \\
\%\end{array}$ & $\begin{array}{l}\text { Neutral } \\
\%\end{array}$ & $\begin{array}{l}\text { Agree } \\
\%\end{array}$ & $\begin{array}{l}\text { Strongly } \\
\text { agree \% }\end{array}$ \\
\hline \multirow{7}{*}{1.} & \multirow{7}{*}{ Transformational } & Missing & - & - & 0.18 & 0.27 & 0.27 & 0.27 \\
\hline & & $20-30$ & 0.18 & 0.36 & 1.08 & 1.71 & 9.99 & 9.72 \\
\hline & & $31-40$ & 0.09 & 0.36 & 1.08 & 2.61 & 14.04 & 9.36 \\
\hline & & $41-50$ & 0.45 & 0.63 & 0.45 & 2.52 & 15.93 & 8.01 \\
\hline & & $51-60$ & - & 0.09 & 1.08 & 1.17 & 9.90 & 3.60 \\
\hline & & $61-70$ & - & 0.09 & 0.09 & 0.18 & 2.43 & 1.08 \\
\hline & & $70 \&$ above & 0.09 & - & - & - & 0.36 & 0.27 \\
\hline \multirow{7}{*}{2.} & \multirow{7}{*}{ Authentic } & Missing & - & - & 0.09 & 0.09 & 0.45 & 0.36 \\
\hline & & $20-30$ & 0.18 & 0.18 & 1.26 & 3.96 & 12.96 & 4.50 \\
\hline & & $31-40$ & 0.27 & 0.54 & 0.54 & 4.86 & 14.58 & 6.75 \\
\hline & & $41-50$ & - & 0.27 & 1.35 & 3.51 & 14.13 & 8.73 \\
\hline & & $51-60$ & - & - & 0.54 & 2.43 & 9.09 & 3.78 \\
\hline & & $61-70$ & - & 0.18 & 0.09 & 0.54 & 2.07 & 0.99 \\
\hline & & $70 \&$ above & 0.09 & 0.09 & - & - & 0.45 & 0.09 \\
\hline
\end{tabular}




\begin{tabular}{|c|c|c|c|c|c|c|c|c|}
\hline \multirow{7}{*}{3.} & \multirow{7}{*}{$\begin{array}{l}\text { Participative/ } \\
\text { Democratic }\end{array}$} & Missing & - & 0.09 & 0.09 & - & 0.54 & 0.27 \\
\hline & & $20-30$ & 0.09 & 0.72 & 1.62 & 1.89 & 12.15 & 6.57 \\
\hline & & $31-40$ & 0.09 & 0.72 & 2.70 & 2.52 & 13.86 & 7.65 \\
\hline & & $41-50$ & 0.18 & 0.90 & 1.71 & 2.61 & 15.12 & 7.47 \\
\hline & & $51-60$ & - & 0.09 & 1.53 & 1.71 & 8.19 & 4.32 \\
\hline & & $61-70$ & - & 0.09 & 0.27 & 0.09 & 2.25 & 1.17 \\
\hline & & $70 \&$ above & 0.09 & - & 0.09 & - & 0.27 & 0.27 \\
\hline \multirow{7}{*}{4.} & \multirow{7}{*}{ Strategic } & Missing & - & 0.09 & 0.18 & 0.18 & 0.45 & 0.09 \\
\hline & & $20-30$ & 0.18 & 0.54 & 1.08 & 5.31 & 10.17 & 5.76 \\
\hline & & $31-40$ & 0.27 & 0.63 & 1.89 & 6.12 & 12.51 & 6.12 \\
\hline & & $41-50$ & 0.18 & 0.36 & 2.43 & 5.13 & 14.58 & 5.31 \\
\hline & & $51-60$ & 0.36 & 0.27 & 0.72 & 2.79 & 8.82 & 2.88 \\
\hline & & $61-70$ & 0.09 & 0.09 & 0.36 & 0.54 & 1.89 & 0.90 \\
\hline & & $70 \&$ above & 0.09 & - & 0.09 & 0.09 & 0.36 & 0.09 \\
\hline \multirow{7}{*}{5.} & \multirow{7}{*}{ Task-Oriented } & Missing & - & - & 0.27 & 0.27 & 0.36 & 0.09 \\
\hline & & $20-30$ & 0.09 & 0.18 & 1.89 & 6.03 & 10.35 & 4.50 \\
\hline & & $31-40$ & 0.27 & 0.81 & 1.62 & 6.39 & 13.14 & 5.31 \\
\hline & & $41-50$ & 0.36 & 0.27 & 2.07 & 4.95 & 14.13 & 6.21 \\
\hline & & $51-60$ & 0.09 & 0.36 & 0.99 & 4.14 & 7.29 & 2.97 \\
\hline & & $61-70$ & - & 0.18 & 0.09 & 0.81 & 2.25 & 0.54 \\
\hline & & $70 \&$ above & 0.09 & - & - & 0.09 & 0.27 & 0.27 \\
\hline \multirow{7}{*}{6.} & \multirow{7}{*}{ Supportive } & Missing & - & - & 0.09 & 0.09 & 0.72 & 0.09 \\
\hline & & $20-30$ & 0.45 & 0.27 & 1.26 & 6.66 & 9.81 & 4.59 \\
\hline & & $31-40$ & 0.36 & 0.72 & 1.26 & 7.92 & 12.42 & 4.86 \\
\hline & & $41-50$ & 0.27 & 0.81 & 1.71 & 7.20 & 12.87 & 5.13 \\
\hline & & $51-60$ & 0.27 & 0.09 & 1.17 & 3.96 & 8.10 & 2.25 \\
\hline & & $61-70$ & 0.09 & 0.18 & 0.09 & 0.54 & 2.07 & 0.90 \\
\hline & & $70 \&$ above & 0.09 & - & - & 0.36 & 0.18 & 0.09 \\
\hline \multirow{7}{*}{7.} & \multirow{7}{*}{ Situational } & Missing & - & 0.09 & 0.27 & 0.18 & 0.36 & 0.09 \\
\hline & & $20-30$ & 0.27 & 0.36 & 1.80 & 7.47 & 9.18 & 3.96 \\
\hline & & $31-40$ & 0.36 & 0.45 & 2.43 & 11.07 & 8.91 & 4.32 \\
\hline & & $41-50$ & 0.18 & 0.54 & 3.51 & 9.63 & 11.61 & 2.52 \\
\hline & & $51-60$ & 0.27 & 0.27 & 1.17 & 4.77 & 7.83 & 1.53 \\
\hline & & $61-70$ & - & 0.09 & 0.36 & 0.99 & 1.98 & 0.45 \\
\hline & & $70 \&$ above & 0.09 & - & - & 0.18 & 0.45 & - \\
\hline
\end{tabular}

Source: Field Survey

Crosstab with Education Group by Leadership Style

\begin{tabular}{|c|c|c|c|c|c|c|c|c|}
\hline \multirow{2}{*}{ S.N. } & \multirow{2}{*}{ Leadership Style } & \multirow{2}{*}{ Age Group } & \multicolumn{6}{|c|}{ Rating } \\
\hline & & & $\begin{array}{l}\text { Missing } \\
\%\end{array}$ & $\begin{array}{l}\text { Strongly } \\
\text { disagree } \\
\%\end{array}$ & $\begin{array}{l}\text { Disagree } \\
\%\end{array}$ & $\begin{array}{l}\text { Neutral } \\
\%\end{array}$ & $\begin{array}{l}\text { Agree } \\
\%\end{array}$ & $\begin{array}{l}\text { Strongly } \\
\text { agree \% }\end{array}$ \\
\hline \multirow{7}{*}{1.} & \multirow{7}{*}{ Transformational } & Missing & - & - & 0.09 & 0.27 & 0.63 & 0.27 \\
\hline & & Under SLC & 0.09 & 0.09 & 0.18 & 0.18 & 2.07 & 0.63 \\
\hline & & SLC-10+2/I.A. & 0.18 & 0.27 & 0.63 & 0.54 & 6.48 & 3.69 \\
\hline & & Bachelor & 0.27 & 0.81 & 1.17 & 3.24 & 15.75 & 11.88 \\
\hline & & Master & 0.27 & 0.36 & 1.80 & 4.05 & 26.64 & 15.03 \\
\hline & & $\mathrm{PhD}$ & - & - & 0.09 & 0.18 & 1.26 & 0.63 \\
\hline & & If Any & - & - & - & - & 0.09 & 0.18 \\
\hline \multirow{7}{*}{2.} & \multirow{7}{*}{ Authentic } & Missing & - & - & 0.09 & 0.18 & 0.81 & 0.18 \\
\hline & & Under SLC & - & 0.18 & 0.18 & 0.72 & 1.71 & 0.45 \\
\hline & & SLC-10+2/I.A. & - & 0.09 & 0.54 & 2.25 & 6.21 & 2.70 \\
\hline & & Bachelor & 0.36 & 0.36 & 1.35 & 4.32 & 18.18 & 8.55 \\
\hline & & Master & 0.18 & 0.63 & 1.53 & 7.74 & 25.29 & 12.78 \\
\hline & & $\mathrm{PhD}$ & - & - & 0.18 & 0.09 & 1.35 & 0.54 \\
\hline & & If Any & - & & - & 0.09 & 0.18 & - \\
\hline \multirow{7}{*}{3.} & \multirow{7}{*}{$\begin{array}{l}\text { Participative/ } \\
\text { Democratic }\end{array}$} & Missing & - & 0.09 & - & 0.18 & 0.63 & 0.36 \\
\hline & & Under SLC & - & 0.36 & 0.18 & 0.63 & 1.53 & 0.54 \\
\hline & & SLC-10+2/I.A. & 0.09 & 0.18 & 0.99 & 1.26 & 6.39 & 2.88 \\
\hline & & Bachelor & 0.18 & 0.90 & 2.88 & 3.33 & 16.74 & 9.09 \\
\hline & & Master & 0.18 & 1.08 & 3.69 & 3.42 & 25.92 & 13.86 \\
\hline & & $\mathrm{PhD}$ & - & - & 0.18 & - & 1.17 & 0.81 \\
\hline & & If Any & - & - & 0.09 & - & - & 0.18 \\
\hline
\end{tabular}




\begin{tabular}{|c|c|c|c|c|c|c|c|c|}
\hline \multirow{7}{*}{4.} & \multirow{7}{*}{ Strategic } & Missing & - & 0.09 & 0.18 & 0.27 & 0.63 & 0.09 \\
\hline & & Under SLC & - & 0.09 & 0.27 & 1.26 & 1.35 & 0.27 \\
\hline & & SLC-10+2/I.A. & 0.36 & 0.54 & 1.26 & 3.06 & 4.59 & 1.98 \\
\hline & & Bachelor & 0.45 & 0.27 & 2.70 & 6.03 & 17.10 & 6.57 \\
\hline & & Master & 0.18 & 0.99 & 2.25 & 9.45 & 23.67 & 11.61 \\
\hline & & $\mathrm{PhD}$ & - & - & - & 0.09 & 1.26 & 0.63 \\
\hline & & If Any & - & - & - & & 0.18 & - \\
\hline \multirow{7}{*}{5.} & \multirow{7}{*}{ Task-Oriented } & Missing & - & - & - & 0.36 & 0.90 & - \\
\hline & & Under SLC & - & 0.18 & 0.45 & 0.90 & 1.17 & 0.54 \\
\hline & & SLC-10+2/I.A. & 0.18 & 0.18 & 1.35 & 2.88 & 5.49 & 1.71 \\
\hline & & Bachelor & 0.36 & 0.63 & 2.16 & 7.56 & 15.93 & 6.48 \\
\hline & & Master & 0.18 & 0.72 & 2.88 & 10.53 & 23.04 & 10.80 \\
\hline & & $\mathrm{PhD}$ & 0.18 & 0.09 & 0.09 & 0.36 & 1.08 & 0.36 \\
\hline & & If Any & - & - & - & 0.09 & 0.18 & - \\
\hline \multirow{7}{*}{6.} & \multirow{7}{*}{ Supportive } & Missing & - & - & - & 0.09 & 0.99 & 0.18 \\
\hline & & Under SLC & 0.18 & 0.36 & 0.09 & 0.72 & 1.35 & 0.54 \\
\hline & & SLC-10+2/I.A. & 0.18 & 0.27 & 0.81 & 2.79 & 4.86 & 2.88 \\
\hline & & Bachelor & 0.72 & 0.72 & 2.07 & 9.00 & 15.03 & 5.58 \\
\hline & & Master & 0.27 & 0.72 & 2.34 & 13.59 & 22.86 & 8.37 \\
\hline & & $\mathrm{PhD}$ & 0.18 & - & 0.27 & 0.45 & 0.90 & 0.36 \\
\hline & & If Any & - & - & - & 0.09 & 0.18 & - \\
\hline \multirow{7}{*}{7.} & \multirow{7}{*}{ Situational } & Missing & - & 0.09 & 0.18 & 0.18 & 0.63 & 0.18 \\
\hline & & Under SLC & - & - & 0.45 & 0.99 & 1.62 & 0.18 \\
\hline & & SLC-10+2/I.A. & 0.18 & 0.18 & 1.62 & 3.87 & 4.41 & 1.53 \\
\hline & & Bachelor & 0.63 & 0.81 & 2.61 & 11.70 & 12.78 & 4.59 \\
\hline & & Master & 0.18 & 0.72 & 4.50 & 16.92 & 19.89 & 5.94 \\
\hline & & $\mathrm{PhD}$ & 0.18 & - & 0.18 & 0.54 & 0.81 & 0.45 \\
\hline & & If Any & - & - & - & 0.09 & 0.18 & - \\
\hline
\end{tabular}

Source: Field Survey

Crosstab with Gender Group by Leadership Style

\begin{tabular}{|c|c|c|c|c|c|c|c|c|}
\hline \multirow[b]{2}{*}{ S.N. } & \multirow[b]{2}{*}{$\begin{array}{l}\text { Leadership } \\
\text { Style }\end{array}$} & \multirow[b]{2}{*}{ Age Group } & \multicolumn{6}{|l|}{ Rating } \\
\hline & & & $\begin{array}{l}\text { Missing } \\
\%\end{array}$ & $\begin{array}{l}\text { Strongly } \\
\text { disagree } \\
\%\end{array}$ & $\begin{array}{l}\text { Disagree } \\
\%\end{array}$ & $\begin{array}{l}\text { Neutral } \\
\%\end{array}$ & $\begin{array}{l}\text { Agree } \\
\%\end{array}$ & $\begin{array}{l}\text { Strongly } \\
\text { agree \% }\end{array}$ \\
\hline \multirow{3}{*}{1.} & \multirow{3}{*}{ Transformational } & Male & 0.63 & 1.26 & 3.78 & 6.84 & 47.79 & 26.19 \\
\hline & & Female & 0.18 & 0.18 & 0.18 & 1.62 & 5.13 & 5.94 \\
\hline & & If Any & - & 0.09 & - & - & - & 0.18 \\
\hline \multirow{3}{*}{2.} & \multirow{3}{*}{ Authentic } & Male & 0.36 & 0.81 & 3.87 & 12.33 & 47.25 & 21.87 \\
\hline & & Female & 0.18 & 0.45 & - & 2.97 & 6.39 & 3.24 \\
\hline & & If Any & - & - & - & 0.09 & 0.09 & 0.09 \\
\hline \multirow{3}{*}{3.} & \multirow{3}{*}{$\begin{array}{l}\text { Participative/ } \\
\text { Democratic }\end{array}$} & Male & 0.36 & 2.52 & 6.57 & 7.47 & 46.80 & 22.77 \\
\hline & & Female & 0.09 & 0.09 & 1.35 & 1.35 & 5.58 & 4.77 \\
\hline & & If Any & - & - & 0.09 & - & - & 0.18 \\
\hline \multirow{3}{*}{4.} & \multirow{3}{*}{ Strategic } & Male & 0.99 & 1.71 & 6.03 & 16.38 & 43.56 & 17.82 \\
\hline & & Female & 0.18 & 0.27 & 0.72 & 3.78 & 5.04 & 3.24 \\
\hline & & If Any & - & - & - & - & 0.18 & 0.09 \\
\hline \multirow{3}{*}{5.} & \multirow{3}{*}{ Task-Oriented } & Male & 0.72 & 1.62 & 5.58 & 19.44 & 42.75 & 16.38 \\
\hline & & Female & 0.18 & 0.18 & 1.26 & 3.24 & 4.95 & 3.42 \\
\hline & & If Any & - & - & 0.09 & - & 0.09 & 0.09 \\
\hline \multirow{3}{*}{6.} & \multirow{3}{*}{ Supportive } & Male & 1.35 & 1.80 & 5.04 & 22.95 & 40.86 & 14.49 \\
\hline & & Female & 0.18 & 0.18 & 0.54 & 3.78 & 5.22 & 3.33 \\
\hline & & If Any & - & 0.09 & - & - & 0.09 & 0.09 \\
\hline \multirow{3}{*}{7.} & \multirow{3}{*}{ Situational } & Male & 1.08 & 1.62 & 8.46 & 29.88 & 35.10 & 10.35 \\
\hline & & Female & 0.09 & 0.18 & 1.08 & 4.41 & 5.04 & 2.43 \\
\hline & & If Any & - & - & - & - & 0.18 & 0.09 \\
\hline
\end{tabular}

Source: Field Survey 
Crosstab with Occupation Group by Leadership Style

\begin{tabular}{|c|c|c|c|c|c|c|c|c|}
\hline \multirow[b]{2}{*}{ S.N. } & \multirow[b]{2}{*}{$\begin{array}{l}\text { Leadership } \\
\text { Style }\end{array}$} & \multirow[b]{2}{*}{ Age Group } & \multicolumn{6}{|l|}{ Rating } \\
\hline & & & $\begin{array}{l}\text { Missing } \\
\%\end{array}$ & $\begin{array}{l}\text { Strongly } \\
\text { disagree } \\
\%\end{array}$ & $\begin{array}{l}\text { Disagree } \\
\%\end{array}$ & $\begin{array}{l}\text { Neutral } \\
\%\end{array}$ & $\begin{array}{l}\text { Agree } \\
\%\end{array}$ & $\begin{array}{l}\text { Strongly } \\
\text { agree \% }\end{array}$ \\
\hline \multirow[b]{2}{*}{1.} & \multirow{2}{*}{ Transformational } & Security Officer & 0.27 & 0.36 & 0.81 & 1.35 & 17.46 & 7.83 \\
\hline & & Public/Private & 0.54 & 1.17 & 3.15 & 7.11 & 35.46 & 24.48 \\
\hline \multirow{2}{*}{2.} & \multirow{2}{*}{ Authentic } & Security Officer & - & 0.36 & 1.26 & 2.79 & 16.02 & 7.65 \\
\hline & & Public/Private & 0.54 & 0.90 & 2.61 & 12.60 & 37.71 & 17.55 \\
\hline \multirow{2}{*}{3.} & \multirow{2}{*}{$\begin{array}{l}\text { Participative/ } \\
\text { Democratic }\end{array}$} & Security Officer & 0.09 & 1.08 & 1.17 & 1.80 & 16.29 & 7.65 \\
\hline & & Public/Private & 0.36 & 1.53 & 6.84 & 7.02 & 36.09 & 20.07 \\
\hline \multirow{2}{*}{4.} & \multirow{2}{*}{ Strategic } & Security Officer & 0.18 & 0.36 & 1.89 & 3.24 & 15.84 & 6.57 \\
\hline & & Public/Private & 0.99 & 1.62 & 4.86 & 16.92 & 32.94 & 14.58 \\
\hline \multirow{2}{*}{5.} & \multirow{2}{*}{ Task-Oriented } & Security Officer & 0.09 & 0.63 & 1.53 & 4.32 & 15.12 & 6.39 \\
\hline & & Public/Private & 0.81 & 1.17 & 5.40 & 18.36 & 32.67 & 13.50 \\
\hline \multirow{2}{*}{6.} & \multirow{2}{*}{ Supportive } & Security Officer & 0.27 & 0.54 & 1.26 & 6.93 & 14.31 & 4.77 \\
\hline & & Public/Private & 1.26 & 1.53 & 4.32 & 19.80 & 31.86 & 13.14 \\
\hline \multirow[b]{2}{*}{7.} & \multirow{2}{*}{ Situational } & Security Officer & 0.09 & 0.45 & 2.34 & 10.17 & 11.16 & 3.87 \\
\hline & & Public/Private & 1.08 & 1.35 & 7.20 & 24.12 & 29.16 & 9.00 \\
\hline
\end{tabular}

Source: Field Survey

ANNEX: VI

\section{Head Personalities}

\begin{tabular}{|c|c|c|c|c|c|c|}
\hline \multirow{2}{*}{ Description } & \multicolumn{3}{|c|}{$\begin{array}{l}\text { Part One } \\
1950 \text { to } 1989 \\
(39 \text { Years }) \\
\end{array}$} & \multicolumn{3}{|c|}{$\begin{array}{l}\text { Part Two } \\
1990 \text { to 30th of May } 2015 \\
(25 \text { Years })\end{array}$} \\
\hline & $\begin{array}{l}\text { Total } \\
\text { Number }\end{array}$ & $\begin{array}{l}\text { Average } \\
\text { Year of } \\
\text { Service } \\
\end{array}$ & $\begin{array}{l}\text { Number of } \\
\text { Person } \\
\text { Repeated } \\
\end{array}$ & $\begin{array}{l}\text { Total } \\
\text { Number }\end{array}$ & $\begin{array}{l}\text { Average } \\
\text { Year of } \\
\text { Service } \\
\end{array}$ & $\begin{array}{l}\text { Number of } \\
\text { Person } \\
\text { Repeated } \\
\end{array}$ \\
\hline Prime-Minister & 19 & 2.05 & 6 & 22 & 1.14 & 5 \\
\hline Home Minister & 34 & 1.15 & 6 & 29 & 0.86 & 5 \\
\hline Chief Secretary & 11 & 3.55 & 0 & 12 & 2.08 & 0 \\
\hline Home Secretary & 15 & 2.60 & 1 & 24 & 1.04 & 2 \\
\hline Chief of Army & 11 & 3.55 & 0 & 7 & 3.57 & 0 \\
\hline $\begin{array}{l}\text { Chief of Nepal Police } \\
\text { Chief of National } \\
\text { Investigation }\end{array}$ & 13 & 3.00 & 0 & 13 & 1.92 & 1 \\
\hline Department & 9 & 4.33 & 2 & 8 & 3.13 & 1 \\
\hline Chief of Armed Police & Not & Not & Not & & & \\
\hline Force (14 Years) & Established & Established & Established & 7 & 2.00 & 0 \\
\hline
\end{tabular}

Source: Office of Prime Minister and Council of Ministers of Nepal, Ministry of Home Affairs of Nepal,

http://en.wikipedia.org/wiki/List_of_Prime_Ministers_of_Nepal, Editor/Publisher-Gopal Budhathoki, Sanghu Saptahik (Sanghu Weekly Nepal). 